\title{
Judeans in the Murašû Archive
}

\subsection{Introduction}

The Murašu archive was the most important source for the study of Judeans in Babylonia until the publication of the texts from the environs of Yāhūdu. ${ }^{861}$ The archive consists of circa 730 texts $^{862}$ relating to the business activities of the descendants of Murašû in the Nippur region from the tenth year of Artaxerxes I to the first year of Artaxerxes II (454-404 BCE). ${ }^{863}$ The Babylonian family of the Murašûs were entrepreneurs in the land-for-service sector of local agriculture, and their archive is an indispensable witness to this economic sphere and the role of immigrants in it.

This chapter is divided into six sections. Sections 5.2 and 5.3 focus on Judean farmers and landholders in the Nippur countryside, and Sections 5.4 and 5.5 discuss Judean officials and witnesses. Sections 5.6 and 5.7 analyse the socioeconomic status and cultural traits of the Judeans in the Murašû archive.

\subsubsection{The Murašû Archive}

The Murašû archive was found in situ in Nippur during the American excavations led by John Henry Haynes in May and June of 1893. The clay tablets and twenty clay bullae were unearthed in a small room in the so-called Camp Hill, west of the Inanna temple and Ekur. As no excavation reports were published, only meagre information on the archaeological context can be obtained from Haynes' field notes and letters. According to them, the tablets were discovered in a single room which was part of a larger house. ${ }^{864}$ The bulk of the clay tablets were divided between Istanbul and Philadelphia, and currently they are kept at the Istanbul Archaeological Museum and the University of Pennsylvania Museum of Archaeology and Anthropology. A number of tablets found

861 This chapter has benefitted from the working notes on the Murašû texts by Govert van Driel and his students (see van Driel 1989, 227 n. 1), archived at Leiden University. Particularly helpful were the transliterations of the texts in PBS 2/1 and van Driel's geographical classification of the texts according to the respective canals and settlements. In the following discussion, these working notes are referred to as 'van Driel, working notes'.

862 Stolper 1985, 14; Jursa 2005a, 113.

863 Stolper 1985, 23.

864 Stolper 1985, 1, 157-168. On the history of early American excavations in Nippur, see Meade 1974, 47-63. 
their way to Jena, Yale, the British Museum, and other collections. ${ }^{865}$ Hermann V. Hilprecht and Albert T. Clay published a significant number of Murašû tablets in 1898-1912, and Matthew W. Stolper and Veysel Donbaz continued their work in the last quarter of the twentieth century. ${ }^{866}$ In addition to these major publications, small groups of tablets have been made available in several publications. $^{867}$

Unlike the Neo-Babylonian cuneiform documents in general, the texts from the Murašu archive hardly ever identify persons using three-tier genealogies with family names. ${ }^{868}$ Thus, the members of the Murašu family are not descendants of an eponymous ancestor from time immemorial but the sons and grandsons of Murašû, son of Hatin, who is attested in two early documents of the archive. ${ }^{869}$ The chief protagonists of the family were Enlil-šum-iddin (active in 445/444-421 ВСE) and his nephew Rīmūt-Ninurta (429-415/414 BCE), ${ }^{870}$ but the servants of the family also play a prominent role in the archive, the most important of them being Rībātu/Bēl-erība. ${ }^{871}$ Although family names cannot be used to link the Murašu family to a specific segment of society, their residence in Nippur, ${ }^{872}$ high socio-economic status, ${ }^{873}$ and personal names referring to Enlil and Ninurta, the chief deities of Nippur, indicate that they belonged to the urban Nippurean upper class.

The business activities of the Murašu family took place in a certain economic sphere. ${ }^{874}$ Persian aristocracy and high officials administered royal

865 Stolper 1985, 11; 2001, 84-85.

866 Hilprecht and Clay 1898 (BE 9); Clay 1904 (BE 10); Clay 1912 (PBS 2/1). Three tablets (nos. 124, 126, and 127) in Clay 1908 (BE 8) belong to the Murašû archive. Stolper's 1974 dissertation is published as Stolper 1985 (EE). The tablets in Istanbul are published in Donbaz and Stolper 1997 (IMT). On the publication history, see Cardascia 1951, ii-iii; Stolper 1985, 11-14; 2001, 83-84. Texts from BE 9 and BE 10 have been recently transliterated by Gauthier Tolini and texts from PBS $2 / 1$ by Denis Bouder (http://www.achemenet.com).

867 Lutz 1928 (UCP 9/3); nos. 124, 145-148, 180, 182-191, 203-204 in Krückmann 1933 (TuM 2-3); nos. 40-42, 63-70, 72-88 in Joannès 1987; no. 126 in Spar and von Dassow 200o; nos. 1-6 in Stolper 2001.

868 Wunsch 2014, 295 + n. 21; Zadok 2015a, 103.

869 Stolper 1985, 19.

870 Stolper $1985,18-20$.

871 Cardascia 1951, 11-17.

872 The archive was unearthed in Nippur and the majority of documents were drafted there. See Stolper 1985, 24.

873 This is suggested by the size of their transactions (Stolper 1985, 125-151), their role in the agricultural management in the Nippur region (Stolper 1985, passim), and slave ownership (Cardascia 1951, 11-17).

874 This overview is based on Cardascia 1951; Stolper 1985; van Driel 1989, 2002, 226-322; Jursa 2010a, 405-414; 2011a, 435-437. 
lands in the Nippur countryside, and smaller landholdings, attached to larger administrative units, were given to individual farmers or families to cultivate. The basic structure of this land-for-service scheme resembles the one we encountered in the texts from the surroundings of Yāhūdu: people - often of foreign origin - were settled on royal lands, given a plot to cultivate, and expected to pay taxes and perform service in exchange. Like in Yāhūdu, the farmers of the state lands are occasionally called šušānus in the documents, and they were part of a complex hierarchical structure of land tenure. The typical designation of a single plot of land remained bìt qašti ('bow land'). However, the system developed over time and some terms which are not attested in Yāhūdu figure prominently in the Murašu texts. The two most important of these are the hatru and šaknu. The former refers to the organisational units into which the holders of bow lands and other crown properties were grouped, and the latter to the official who was in charge of land tenure and the fulfilment of obligations in a given hatru.

The Murašu archive documents the business transactions of a family of entrepreneurs working in the land-for-service sector. The archive consists of promissory notes, leases, receipts, and other legal texts primarily relating to credit granting and agricultural management. ${ }^{875}$ The Murašûs served as middlemen between small landholders and the administrative apparatus, as they facilitated the payment of taxes by granting credit to landholders. The Murašus received payments from the farmers in agricultural produce but paid rent and taxes primarily in silver; retail sales of produce were an essential part of their business, as is shown by a number of texts on beer brewing in the archive. ${ }^{876}$ The Murašûs also managed the cultivation of royal lands in the Nippur region. They acquired landholdings in two ways: first, they leased land and water rights directly from the representatives of the crown. Second, they granted credit to farmers in the land-for-service sector and gained control over the plots that were pledged to secure the debts. The Murašûs then subleased lands, water rights, and draught animals to tenants, including the actual holders of the pledged lands.

In contrast to the abundance of business documents in the Murašu archive, there are no texts referring to the family's houses or other property than slaves. This implies that the present archive is a selection of tablets removed from the

875 On the business profile of the Murašûs, see Stolper 1985, 2005; van Driel 1989; Jursa 2010a, 198-199, 405-414; Pirngruber 2017, 47-66.

876 van Driel 1989, 225-226. 
main archive when not needed anymore. ${ }^{877}$ However, it remains unclear who was responsible for selecting the texts that remain to us. This uncertainty is caused by the last documents of the archive, which do not refer to the Murašûs anymore but to a certain Enlil-supê-muhur, a former servant of the family. ${ }^{878}$ After the Murašûs disappeared, Enlil-supê-muhur worked as the paqdu ('manager') of Prince Aršam, leasing out the prince's herds of sheep and goats. Here private business, the interests of the crown, and administrative mechanisms of the land-for-service sector seem to be intertwined, like in the texts from Yāhūdu and its surroundings.

\subsubsection{Judeans in the Murašû Archive}

The economic and legal aspects of the Murašu archive have been thoroughly studied, ${ }^{879}$ and the ethnic and onomastic diversity in the Nippur region has been surveyed in several studies. ${ }^{880}$ However, there has been less interest in the life of the people figuring in the archive. This applies to the Murašus themselves, as well as to their clients, many of whom were descendants of foreign deportees. The social and religious history of Judeans in the Nippur region has been briefly discussed by Daiches, Bickerman, and Zadok, ${ }^{881}$ and although the presence of Judeans in the Murašû archive is acknowledged in most studies dealing with the Babylonian exile, only a page or two is normally devoted to discussing the material.

Although the Murašu archive documents business activities from the viewpoint of the archive-holding family, it is a relatively rich source for the study of Judeans in Babylonia. Altogether 61 Judean individuals appear in 64 different documents, making the archive the most extensive source for the study of Judeans after the texts from Yāhūdu and its surroundings. ${ }^{882}$

The documents pertaining to Judeans cover the whole chronological span of the archive. A Judean is already attested in the second earliest text of the archive from the thirteenth year of Artaxerxes I (BE $93,45^{2} \mathrm{BCE}$ ), and another Judean features in the late Aršam group in the eleventh year of Darius II (PBS 2/1 148, 413 BCE). Moreover, the chronological distribution of the documents

877 van Driel 1989, 203-204, 223-226; Jursa 2005a, 113. Stolper 1985 $\left(28-29,15^{2-156)}\right.$ has different ideas about the end of the archive, but see Stolper 2001, 85 .

878 Stolper 1985, 23-24; van Driel 1989, 204; Jursa 2005a, 113 .

879 Cardascia 1951; Stolper 1985, 2005; van Driel 1989, 2002, 155-322; Jursa 2010a, esp. 405-414; Gordin and Zadok 2016.

88o Coogan 1976a; Eph'al 1978; Zadok 1979a, 2002, 2015a; Dandamayev 2004; Lämmerhirt 2014.

881 Daiches 1910; Bickerman 1978, 1984; Zadok 1979a.

882 A prosopographical database of Judeans in the Murašu archive is available online at https://doi.org/10.5281/zenodo.3351259. 


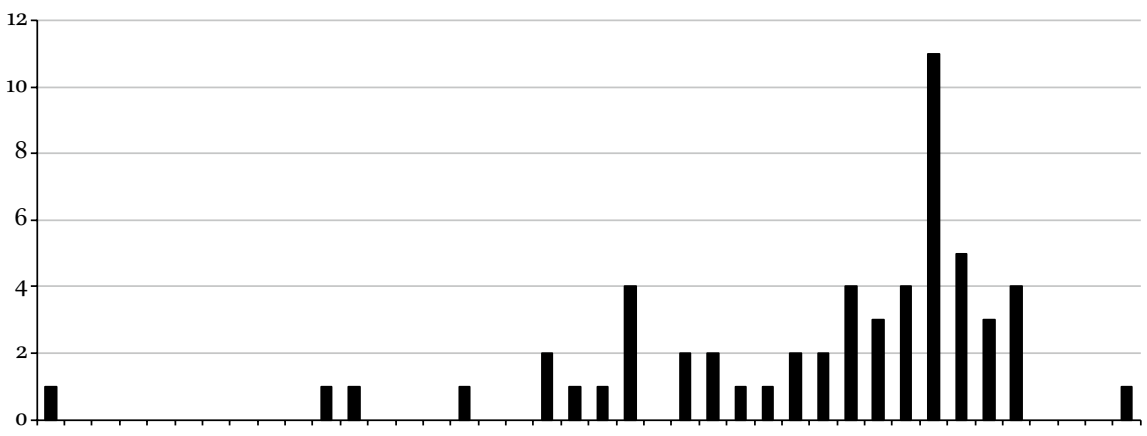

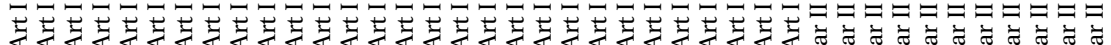

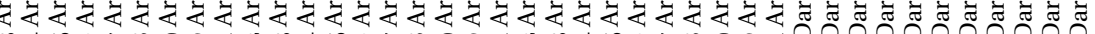

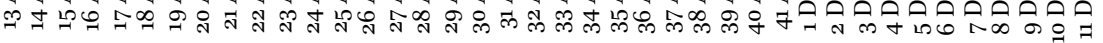

FIGURE 9 Murašû texts pertaining to Judeans

featuring Judeans also fits the distribution of the whole archive. As the graphs presented in Donbaz and Stolper 1997 clearly show, ${ }^{883}$ the fortieth year of Artaxerxes I marks a watershed in the chronological distribution of the tablets in the archive, as the majority of documents were written during a period of peak activity in 40 Art I - 7 Dar II (425-417 BCE). The same pattern can be seen in Figure 9, which records the datable transactions pertaining to Judeans in the Murašû archive.

Some features of Figure 9 require explanation. First, the peak in the thirtyfourth year of Artaxerxes I is incidental, and it results from the fact that PiliYâma/Šillimu happened to witness three documents in Nippur on the same day (BE 9 34; IMT 7, 8). Second, there is no peak in the number of documents from the last year of Artaxerxes I and the first year of Darius II. In the archive as a whole, the peak in these two years results from the large number of debts to the Murašûs by landholders whose plots were pledged to secure the debts. As Stolper suggests, these mortgages may have resulted from the financial difficulties that farmers in the Nippur region experienced because of the increased burden of tax and service obligations during the fight for the Persian throne after the death of Artaxerxes I. ${ }^{884}$ Some Judeans were also affected by the crisis (BE 1033 ; $\mathrm{PBS} 2 / 127,185$ ), and it remains unclear if the small number of Judeans involved only results from the accidental preservation of texts or if their situation was different from landholders in general. Third, there is a sharp peak in the number of documents pertaining to Judeans in the fourth year of

883 Donbaz and Stolper 1997, 6-10.

884 Stolper 1985, 104-124; Donbaz and Stolper 1997, 5-15; Jursa and Stolper 2007, 270. Cf. van Driel 1989, 223-224. 
Darius II. This year is very well documented in the archive in general, but such a steep rise in numbers is unexpected. There seems to be no common denominator between the eleven texts, and Judeans are attested as witnesses, minor officials, landholders, and creditors. Given the small sample of texts pertaining to Judeans, this anomaly may be incidental as well.

These statistics indicate that no major changes occurred among the Judean population in the Nippur region in the last half of the fifth century. Because the chronological distribution of Judean texts mirrors that of the archive as a whole, large groups of Judeans hardly migrated to or from the region. As this chapter shows, nothing in the texts suggests that the socio-economic status of Judeans was any different from other deportees in the Nippur countryside, and the statistical anomalies in 41 Art I - 1 Dar II and in 4 Dar II are probably incidental.

\subsubsection{Seal Impressions}

The sealing of cuneiform tablets has a long history in Babylonia. In addition to their legal value, seal impressions conveyed other messages: some seals were connected to a certain office or royal authority, whereas seal use and imagery can shed light on the social status and cultural values of an individual. Accordingly, seal impressions can effectively supplement the picture emerging from the texts themselves. The use of personal seals became increasingly common in the Persian period, and the Murašû archive is a rich source for the study of sealing practices in Babylonia. Judeans followed the general trend: the single Judean seal owner attested before the mid-fifth century is Ahīqam/Rapā-Yāma, who impressed his seal on a single tablet in the twelfth year of Darius I (B9). This changes in the Murašû archive, in which fourteen Judeans used seals, some of them even two different ones. ${ }^{885}$

This remarkable difference is the result of changes in sealing practices in Babylonia from the sixth to the late fifth centuries. ${ }^{886}$ In the archives from the early sixth century, only documents pertaining to the transfer of real estate were sealed, and the sealers belonged to a distinct group of scribes or notaries. The sellers of real estate impressed their nail marks on the tablets, but their seal impressions are never attested. ${ }^{887}$ Sealing practices started to change in the late Neo-Babylonian and early Persian periods: new document types were sealed or marked with nails and sealing was not practised exclusively by scribes. The sealing of a tablet still remained an exception, rather than the rule.

885 BE $925,45,69$; BE 10 65, 83, 118; EE 34, 65, 89, 107; PBS 2/1 5, 50, 60, 84, 107, 119, 218; UCP 9/3.

886 For an overview, see Oelsner 1978.

887 Oelsner 1978, 168-169; Baker and Wunsch 2001. 
The change accelerated in the reign of Darius I, and Ahīqam's use of a seal in Darius' twelfth regnal year should be seen in this context. ${ }^{888}$

Seal use became more widespread during the fifth century, and the Murašû archive is a very rich source for the practice. ${ }^{889}$ The principals who ceded rights or took an obligation rather consistently impressed their seals or nail marks on the tablet, and if judges were present at the transaction, they always used a seal. Impressing a nail mark did not necessarily imply that the person could not afford to buy a seal, as the use of nail marks was preferred in certain types of transactions. ${ }^{890}$ Witnesses occasionally impressed their seals on tablets in the early reign of Artaxerxes I, but this custom changed drastically in the late reign of Artaxerxes I and the early reign of Darius II, when the majority of witnesses sealed tablets. ${ }^{891}$

These developments are the underlying factor for the scarcity of Judean seal owners in the environs of Yāhūdu and their frequent attestation in the Murašû archive. Some Judean seal owners will be treated in the discussion below, and Judean seal use in its socio-economic and cultural context will be treated in Section 5.7.

\subsection{Yadi-Yāma and Pili-Yāma: Entrepreneurs or Representatives?}

The members of the Murašu family are an example of people who worked as middlemen between the state administration and landholders, finding business opportunities within the framework of the land-for-service sector. It is not always easy to determine, however, if people dealing with the Murašu family were landholders in their own right, representatives of a family or community, minor officials of the land-for-service sector, or entrepreneurs who further subleased the landholdings at their disposal. Such a strict classification of roles may even be misleading, as the interplay of family ties, communal and personal interests, and official capacities is common in any human society. An important example of this complexity is a dossier of twelve texts pertaining to Pili-Yāma/Šillimu, Yadi-Yāma/Banā-Yāma, and Yadi-Yāma's son Yāhû-natan. ${ }^{892}$ These Judean men dealt with the Murašûs and the farmers in the village of BìtGērāya in 24-40 Art I (441-425 вСE). A careful analysis of these men and their

888 Oelsner 1978, 168-169; Baker and Wunsch 2001, 203.

889 Bregstein 1993.

890 Bregstein 1993, 340-354.

891 Bregstein 1993, 359-360.

892 BE 9 14, 25, 29, 34, 45; EE 2, 26, 92, 94, 98; IMT 7-8. 
activities sheds light on the communal aspects of landholding in the land-forservice sector. Moreover, it emphasises that people dealing with the Murašûs could be representatives of larger communities, not mere landholders or businessmen.

\subsubsection{Business Partners of the Murašûs?}

The earliest document pertaining to Yadi-Yāma/Banā-Yāma was written in Nippur in 5-V-24 Art I (EE 2). He leased out the Bēl and Mušēzib-Bēl canals and perhaps $u z b \bar{a} r u$ land to Enlil-šum-iddin/Murašû for the annual rent of 200 kurru of produce. ${ }^{893}$ Two documents from the twenty-eighth (BE 9 16) and thirty-first (EE 30) years of Artaxerxes I show that Enlil-šum-iddin later subleased the Bēl canal to his tenants and slaves. ${ }^{894} \mathrm{EE} 2$ is not explicit about the status of Yadi-Yāma, and one might interpret him either as a royal agent or sublessor. According to Stolper, the Murašûs leased canals predominantly - if not exclusively - from the royal administration, but van Driel is open to the possibility of subleases as well. ${ }^{895} \mathrm{EE} 2$ could well be a sublease, judging by the fact that Yadi-Yāma did not bear any official title and that the royal administration is referred to only at the end of the operative part, where Yadi-Yāma guarantees that the canal manager ( $\check{s} a$ muhhi sūti ša nār $\mathrm{d}[\mathrm{x}]$ ) will not contest the lease. This assumption is further supported by the analysis of other documents in this cluster, which show that Yadi-Yāma was involved in the exploitation of canals and adjoining lands rather than their management.

Pili-Yāma/Šillimu appears for the first time in Nippur in 28-X-28 Art I (BE 914). He and Enlil-šum-iddin/Murašû pay the sūtu rent of 97 kurru of millet to the manager of the Sîn canal, the servant (mār bìti) of the mašennu official Artabara. ${ }^{896}$ The payment is due from the land of Bēl ${ }^{897}$ and (a part of) the

893 The lease of a canal probably included the adjoining lands as well, even if this is not made explicit in the contract. See van Driel 1989, 217 n. 25; Stolper 2005, 335. The text of EE 2 is broken, and it is unclear if the $u z b \bar{a} r u$ land was included in or excluded from the lease (see van Driel 2002, 201). Uzbāru was a type of royal land. See Stolper 1985, 41-42; van Driel 2002, 200-202.

894 van Driel, working notes.

895 Stolper 1985, 50; van Driel 1989, 217. But see the somewhat indecisive position taken by Stolper in $2005,335^{-} 336$.

896 On the term mär bìti, see Stolper 1985, 21. Mašennu officials were in charge of royal landholdings and taxation (Stolper 1985, 45-49; Jursa and Stolper 2007, 260), and people called ša ana muhhi sūti ša nār $\mathrm{x}$ ('the one in charge of the rents of the canal $\mathrm{x}$ ') appear to have been their subordinates, either officials directly involved in transactions concerning royal lands and canals (Stolper 1985, 37-45; Stolper 2001, 117) or rent farmers (van Driel 1989, 215; see also Stolper 2005, 335-336). In both cases, the authority of canal managers derived from the crown and they were royal agents in that sense.

897 See Stolper 1985, 42-44. 
Puratti-Nippur canal. The receipt suggests that Pili-Yāma and Enlil-šum-iddin were business partners or at least shared an interest in obtaining rights to land and water from the royal administration or its representatives. The document is witnessed by a certain Šillimu/Pa-ni- $a$, who might be Pili-Yāma's father. ${ }^{898}$

These two texts alone would suggest that Yadi-Yāma and Pili-Yāma appear to be entrepreneurs like the Murašûs, leasing and subletting royal properties in the Nippur countryside. However, their transactions in the following years indicate that they may be better understood as representatives of larger communities, not merely as entrepreneurs acting for their own profit. 899

\subsubsection{Yadi-Yāma and the Village of Bït-Gērāya}

Yadi-Yāma's economic status worsened over time, which is already apparent in the thirty-first year of Artaxerxes I. In a document written in Nippur (BE 925 , 17-I-31 Art I), he leases the Urâti canal, his bit ritti, 'the land for which he is agent' (a.šà $n a-a ́ s ̌ s-p a r-t i-s ̌ u ́),{ }^{900}$ and his pledged property for three years from Enlil-šum-iddin for the annual rent of 200 kurru of barley. The rent was to be paid in a place called Gērāya. Some of his landholdings had apparently been pledged as a security for some previous debt, and they had come into the disposal of Enlil-šum-iddin. In BE 9 25, Yadi-Yāma asks his creditor to lease the pledged lands to Yadi-Yāma himself instead of leasing them to someone else. This transaction is a good example of the business model of the Murašûs: credit granting allowed the family to get hold of land properties, which could be leased back to their actual holders. ${ }^{901}$ The meaning of bit ritti is not completely understood, but it does not seem to denote a specific type of landholding in the land-for-service sector like bìt qašti. In the Murašû archive, it was perhaps more of an umbrella term which could refer to various types of landholdings, sometimes - if not usually - belonging to a temple or the crown. In Hellenistic Uruk, bit ritti properties were closely related to the temple of Anu. ${ }^{902}$ It is quite probable that the bit ritti was not Yadi-Yāma's private property.

Three details of the transaction shed light on Yadi-Yāma's economic role in the land-for-service sector. First, he was the nominal holder of some of the leased lands, not just a businessman taking them on lease. Second, the lease also involved lands (a.šà na-áš-par-ti-šú) that were not Yadi-Yāma's personal

\footnotetext{
898 On the name and person, see Zadok 1979a, 32, 59.

899 As already suggested by Zadok 1979a, 54-58 (Yadi-Yāma as a member of the Banā-Yāma clan); van Driel 2002, 215 (Yadi-Yāma as a member of a group of villagers joining forces).

900 The translation is adopted from CAD N/2, 76 .

901 Stolper 1985, 104-107.

902 On bìt rittis on agricultural land, see van Driel 2002, 305-308 with further literature. On bit rittis in Hellenistic Uruk, see Baker 2005, 30-37; Corò Capitanio 2012.
} 
holdings. Našpartu means 'agency, proxy' or 'service, business' in comparable Neo-Babylonian legal and economic contexts, ${ }^{903}$ and, in the present document, Yadi-Yāma obviously held a plot of land on behalf of other people, or he represented them in the transaction. Third, his sons Yāhû-natan and PadāYāma witnessed the document, and the caption next to Yadi-Yāma's seal impression reads 'the seal of Yadi-Yāma and his brothers'. The explicit reference to a seal owned by several people is unique in the Murašû archive, ${ }^{904}$ and it seems to imply that Yadi-Yāma was not acting only on his own behalf. He represented at least his family or even a larger community, as the word $a h u$ ('brother') often refers to collegial relations in general. ${ }^{905}$ Yadi-Yāma and his sons are, however, the only Judeans attested in this document. In addition to this seal, ${ }^{906}$ YadiYāma also owned another seal, which he impressed on BE $945 \cdot{ }^{907}$ No other Judeans impressed their seals on the documents belonging to this dossier.

Yadi-Yāma's representative role in BE 925 is corroborated by BE 945 (Nippur, 20-V-36 Art I). Enlil-šum-iddin leases water rights and land to Yadi-Yāma, his three sons, a Judean man, four other people, and their anonymous colleagues (kinattu) in Bìt-Gērāya for three years. The leased property consists of the Urâti canal, tithe land (bìt ešrî̀) and Yadi-Yāma's bìt ritti on the banks of the Urâti, lands on the left bank of the Milidu canal, and three plots of land irrigated by waterlifts ${ }^{908}$ on the right bank of the same canal. The annual rent was 700 kurru of barley, two oxen, and twenty sheep, far more than a single farmer could produce in a year. ${ }^{909}$ Here the lessees quite clearly constitute a community of farmers who not only leased new lands to cultivate them, but also sought to retain their hold on Yadi-Yāma's bit ritti. As the interests of the larger group and Yadi-Yāma appear to be intertwined and as BE 925 and 45 partially pertain to the same landholdings, it seems quite certain that Yadi-Yāma's transaction in BE 925 relates to this community of farmers as well. ${ }^{910}$

\footnotetext{
903 CAD N $/ 2,75^{-76}$.

904 Bregstein 1993, 365-366.

$905 \mathrm{CAD} \mathrm{A} / 1,200-203$.

906 Bregstein 1993 no. 578. The seal depicts a nude couple embracing.

907 Bregstein 1993 no. 642. The imagery is unclear.

908 3-ta dìm.me.meš on line 11 may refer to waterlifts (CAD M/1, 143) or, more likely, to plots irrigated by waterlifts (Stolper 2001, 122-123).

909 The average barley yield of a hectare was 1,728 litres in sixth-century Sippar, and the material from Uruk and Sippar show that a single plough team could not work more than 37.5 hectares of land in a ploughing season (Jursa 2010a, 49-50). This means that circa 73 hectares of land and two full plough teams were needed to produce the rent of 700 kurru of barley.

910 van Driel 2002, 215.
} 
This community of farmers should be geographically connected to (Bìt-) Gērāya, ${ }^{911}$ a settlement which was probably located by the canal system fed by the Euphrates of Nippur (Purat Nippur). ${ }^{912}$ The place name is only mentioned in BE 9 25, BE 9 45, and EE 98 (20-IX-36 Art I), which was written in the same village. The latter document (EE 98 ) is a promissory note for 70 vats of beer, owed by a certain Bēl-idrī to Yadi-Yāma. The repayment of the debt was to take place after the next date harvest. If read together only with EE 2, this promissory note would corroborate the idea that Yadi-Yāma was an entrepreneur like the Murašûs, practising agricultural management and turning his revenue of agricultural produce into silver by beer brewing and retail. EE 98 undoubtedly reflects commercial activity, and it might well be connected to the retail of date beer to urban customers. However, as the transaction took place in BìtGērāya only four months after BE 9 45, it is fully possible that Yadi-Yāma did not act only on his own behalf here either. The debtor's name Bēl-idrī cannot be found in any other Murašû document, and thus his identity and the relationship of this transaction to the Murašûs remain unknown. It is noteworthy that both EE 98 and BE 945 were witnessed by Pili-Yāma, while a certain Satturu/Šabbatāya witnessed EE 98 and was Yadi-Yāma's co-lessee in BE 945. EE 98 is the last attestation of Yadi-Yāma.

The village of Bīt-Gērāya was evidently the focal point of Yadi-Yāma's activities. He had colleagues in the village, he was supposed to deliver his rental payment there, and one of his transactions was concluded there. At the same time, the communal aspects of his transactions suggest that he was not merely a businessman working in Bït-Gērāya but more like a representative or foreman of the local community.

\subsubsection{Pili-Yäma's Transactions}

After his first appearance as Enlil-šum-iddin's co-lessee in 28 Art I (BE 9 14), Pili-Yāma is attested five times as a witness before he appears again as a debtor and lessee in 37 and 38(?) Art I (EE 94, 26). In addition to Yadi-Yāma's transactions BE 945 and EE 98, Pili-Yāma witnessed three documents (BE 9 34; IMT 7,8 ) which were written in Nippur in 7-IV-34 Art I by the same scribe before the same witnesses. ${ }^{913}$ All documents are leases of animals and/or land granted by Enlil-šum-iddin to three different lessees. None of the lessees bore a Judean name, and Pili-Yāma had no obvious connection to them. It is possible

\footnotetext{
911 Zadok 1979a, 57.

912 Zadok 1978a, 288-292 (but cf. 318); 2015a, 140.

913 Except for Mukīn-apli/Enlil-na'id, who is attested in IMT 7 and 8 but not in BE 9 34. Cf. Donbaz and Stolper 1997, 84 .
} 
that he happened to be present in Nippur when the documents were written and, being Enlil-šum-iddin's old acquaintance, he was asked to witness the transactions.

Two documents from the late years of Artaxerxes I shed more light on PiliYāma's connections with the Murašu family. The first document is a promissory note for a kur.ra textile ${ }^{914}$ worth 30 shekels of silver, written in Nippur in 26-V-37 Art I (EE 94). The debtor is Pili-Yāma and the creditor Tīrīkāma, a wellknown servant of Enlil-šum-iddin. ${ }^{915}$ The value of the textile is surprisingly high in comparison to the prices of kur.ra textiles from the late seventh to the late sixth century, when the prices fluctuated generally between two and seven shekels of silver. ${ }^{916}$ Although the price of kur.ra textiles rose in the late sixth century, ${ }^{917}$ the general trend of prices in Persian-period northern Babylonia ${ }^{918}$ does not favour the assumption that kur.ra textiles were on average worth half a mina in central Babylonia in the late fifth century. As far as I know, there are no other Murašû texts referring to kur.ra textiles. The textile in EE 94 is described as biršu ${ }^{919}$ eššu, 'coarse (fabric and) new', which does not unequivocally indicate that the high quality of the textile made it exceptionally valuable. As kur.ra was a common type of textile in Babylonia, the promissory note cannot be related to any specific type of economic activity. However, the exceptional value of the textile and the absence of other kur.ra texts in the Murašu archive make this an intriguing document.

The last document (EE 26) pertaining to Pili-Yāma ${ }^{920}$ is a lease of the Badiātu canal of Marduka (nār Badiāti ša Marduka). The transaction is badly broken, but it shows that Pili-Yāma and two other men leased the canal from a member of the Murašû family, most likely Enlil-šum-iddin, around 38 Art I. ${ }^{921}$ In order to understand the context of this transaction, it is necessary to study two earlier documents concerning this branch or part of the Badiātu canal.

In 12-V-32 Art I (BE 9 29), Marduka, the slave of Enlil-šum-iddin, rented the Badiātu canal of Yadi-Yāma (nār Badiāti ša Yadi-Yāma), adjoining lands,

914 On kur.ra textiles, see Bongenaar 1997, 39-40; Zawadzki 2010, esp. 412-414; Spar and Jursa 2014, 67 .

915 Stolper 1985, 21.

916 Jursa 2010a, 619-623.

917 There are some late cases when the price was 7, 7.25, and 13 shekels; see Jursa 2010a, 622.

918 Hackl and Pirngruber 2015.

919 CAD B, 261: 'woolen fabric with raised nap'. Villard 2010, 395: 'de texture grossière' or 'feutré'; according to Villard, the term may indicate fabrics of ordinary finish.

920 Pili-Yāma's name in this text is broken, and only the signs -ia-a-ma A-šá Iše-li-im-mu are fully preserved. However, the remnants of the sign 'li' can be seen before the sign 'ia', and the contents of the transaction make the identification very probable.

921 On the date of this document, see below. 
ploughs, oxen, ${ }^{922}$ and seed corn from his master for three years for the annual rent of 1,025 kurru of produce. ${ }^{923}$ It is likely that the canal was named after its former holder, Yadi-Yāma, although there are no texts which pertain to YadiYāma's tenancy of this canal. Three years later, Pān-Enlil-adaggal, another servant of Enlil-šum-iddin, leased the Badiātu canal of Marduka (nār Badiāti ša Marduka) under similar conditions for three years from Enlil-šum-iddin (IMT 10, 16-XIIb-35 Art I).

In light of these three transactions, 'the Badiātu canal of Marduka' and 'the Badiātu canal of Yadi-Yāma' refer to one and the same canal. The name of the current or previous tenant served as an identification marker which helped to distinguish the canal from other homonymous watercourses or to specify which part of the canal was meant. ${ }^{924}$ Because Pān-Enlil-adaggal's three-year lease was recorded in 35 Art I, Pili-Yāma and his two co-lessees leased the canal after Pān-Enlil-adaggal, probably in 38 Art I (EE 26). ${ }^{925}$

Nothing is known about Yadi-Yāma's tenancy of this branch or part of the Badiātu canal, but given the other documents referring to him, two scenarios are possible: first, Yadi-Yāma leased the canal directly from the royal administration and it came into the possession of Enlil-šum-iddin by a sublease or as a result of Yadi-Yāma's insolvency. Alternatively, Yadi-Yāma leased the canal from Enlil-šum-iddin, like Marduka and others after him. Be that as it may, the Badiātu canal of Yadi-Yāma and Marduka was at the disposal of the Murašûs for almost a decade or more, and the family repeatedly leased it out to its servants and other tenants. The document referring to Pili-Yāma's lease (EE 26) is badly broken, and the names of his two co-lessees survive only as PN/Barik-il and Minyamin/PN. Barīk-il and Minyamin are both West Semitic names, ${ }^{926}$ and the Judean background of these people remains a possibility that cannot be confirmed or excluded. ${ }^{927}$ However, Minyamin is perhaps attested together

922 Only the ploughs are mentioned in the text, but the oxen were likely included as well (Stolper 1985, 132).

923 The sum of the different types of produce is 1,025 kurru, but the tablet gives the sum as 1,015 kurru. See Augapfel 1917, 70.

924 Zadok $(1978 a, 292,314)$ favours the idea that there was more than one Badiātu canal, and the qualifiers were used to distinguish the canals. Both he (292, but cf. 314) and Stolper $(1985,40+$ n. 13) suggest that the Badiātu of Yadi-Yāma and the Badiātu of Marduka were one and the same canal, named after its current tenant.

925 The regnal year of Artaxerxes is damaged in the document, and only three vertical wedges can be read. Stolper $(1985,244)$ restores the number as ' 36 ', but given the three-year lease of Pān-Enlil-adaggal in 16-XIIb-35 Art I (IMT 10), a more probable restoration is ' 38 '.

926 On Barik-il, see Pearce and Wunsch 2014, 44; on Minyamin, see Section 1.5.2.

927 Cf. Zadok 2002, 39. 
with Pili-Yāma in BE 9 45, when a certain Minyamin/Bānia figures on the witness list right after Pili-Yāma. ${ }^{928}$

The information on the extent of the lease and the size of the rent has been mostly destroyed in EE 26 , and only the references to the $\mathrm{Na}^{\text {' }}$ ilti-il canal and 76 kurru of emmer remain. Emmer was usually only a subsidiary component of the annual rent in the leases of canals, ${ }^{929}$ and the extent of the lease in EE 26 may resemble IMT 10, which refers to the fields extending as far as the $\mathrm{Na}^{\text {' }}$ ilti-il canal. As the annual rent in the earlier leases of the Badiātu canal of Yadi-Yāma and Marduka was around 1,00o kurru of produce, it is likely that the scope of EE 26 was roughly the same.

At first glance, Pili-Yāma's transactions could well pertain to his private business. The two leases of canals and the promissory note for a kur.ra textile do not directly pertain to the community of farmers in Bīt-Gērāya. However, Pili-Yāma and Yadi-Yāma shared an interest in the tenancy of one and the same canal, and Pili-Yāma was also connected to Bīt-Gērāya. He witnessed Yadi-Yāma's transaction in the village and another document connected to Yadi-Yāma and his colleagues in Bìt-Gērāya. The leases of the Badiātu canal could have merely been private transactions, but they may also indicate that the canal was important to the community to which the two Judeans belonged.

\subsubsection{Yāhî-natan, Son of Yadi-Yäma}

After Yadi-Yāma and Pili-Yāma disappear from the scene, Yadi-Yāma's son Yāhûnatan appears in yet another lease of the Urâti canal in 29-V-40 Art I (EE 92). He had been involved in the leases of this canal already earlier: he witnessed a lease of the canal in 31 Art I (BE 925 ) and was among his father's co-lessees in 36 Art I (BE 9 45). In EE 92, he and Bānia/Amēl-Nanâ promise Enlil-šum-iddin to perform maintenance work on part of the canal during a two-week period until the twelfth day of the sixth month. This period from late August to early September coincides with the time when the water level in the Euphrates was low after the annual flood season was over. ${ }^{930}$ This was a natural moment to dig canals and repair damage caused by the flood. In compensation for their work, Yāhû-natan and Bānia were granted a lease of the canal, ${ }^{931}$ but it remains unclear how long it was for. In any case, a very short lease, such as only for the

928 Zadok 2002, 39 .

929 According to Stolper $(1985,131)$, barley was the main component of rental payments. For the relative importance of barley and emmer in some leases, see BE 9 29; EE 2; IMT 10.

930 Charles 1988, 6, 38.

931 See Zadok 2002, 37-39. Stolper seems to understand the document similarly, as he inserts $\langle$ bi in-na-na-ši $\rangle$ ('please give it') on line 4 of his transliteration $(1985,271)$. 
duration of the maintenance work, makes little sense from an agricultural perspective.

This document again stresses the fact that Yāhû-natan and Bānia could not have acted alone, but they had to have had a considerable workforce at their disposal. The workers digging the canal were most probably the inhabitants of Bìt-Gērāya, represented here by Yāhû-natan and Bānia. This link is not only suggested by the connections to Yadi-Yāma and the Urâti canal, for Bānia was also a member of the community in Bīt-Gērāya. He was Yadi-Yāma's co-lessee in BE 945 and a witness to Yadi-Yāma's promissory note for beer (EE 98), which was written in Bìt-Gērāya. Furthermore, he might have been the father of Minyamin/Bānia, the aforementioned witness of BE 945 and a possible colessee of Pili-Yāma in EE $26 .{ }^{932}$

\subsubsection{Representatives of a Community of Farmers}

The picture emerging from the documents relating to Yadi-Yāma, Pili-Yāma, and Yāhû-natan is one of men who were capable of organising the cultivation of large tracts of land and mustering a sufficient workforce to dig a canal. In the earliest documents, both Yadi-Yāma and Pili-Yāma deal with Enlil-šum-iddin like business partners, but in the later documents they only appear as tenants of the Murašû family. Yadi-Yāma's economic situation was evidently difficult after the thirtieth year of Artaxerxes I, and his dependency on the Murašus is reflected by the fact that he had to lease his own pledged lands from Enlil-šumiddin. Nothing suggests that the social or professional status of Yadi-Yāma and Pili-Yâma changed over time, and the changes in their economic status may reflect the fact that they were actually the more vulnerable party in their transactions with the Murašu family.

One way to explain Yadi-Yāma's and Pili-Yāma's transactions is to perceive them as entrepreneurs who were engaged in agricultural management, similar to the Murašûs. That would neatly explain the earliest leases: EE 2 would be a sublease of the properties which Yadi-Yāma had leased from the state administration, and in BE 9 14, Pili-Yāma and Enlil-šum-iddin would simply be business partners leasing some royal properties. The later leases would bear testimony to the tenancy of royal lands one step below the Murašu family: the Judean men leased rights to water and land from the Murašûs and then subleased those rights to their tenants. Yadi-Yāma's and Pili-Yāma's profit was generated from the difference between the rent they paid to the Murašus and the rent they charged from their tenants. The reference to date beer perfectly

932 Zadok 1979a, 56, 58. 
fits this entrepreneurial scenario, because brewing was a necessary activity for many business-oriented people in an agricultural setting. ${ }^{933}$

The weakness of the entrepreneurial scenario is the strong communal aspect of Yadi-Yāma's and Pili-Yāma's activities. This is apparent in the lease of the Urâti canal in BE 9 45, in which Yadi-Yāma does not act alone but with eight co-lessees and their unnamed colleagues in Bìt-Gērāya. ${ }^{934}$ The Urâti canal is the subject of two other leases (BE 9 25; EE 92), both of which exhibit strong connections to BE 945 . There is only one more Murašu text (IMT 24) referring to this canal, ${ }^{935}$ but the contents of this small fragment are incomprehensible. The three leases of the Urâti canal not only show that the canal was of great importance to the family of Yadi-Yāma, but all establish a firm connection to the village of Bìt-Gērāya.

Bìt-Gērāya is only attested in three documents in the Murašû archive, all of which are related to Yadi-Yāma's transactions (BE 9 25, 45; EE 98). Several other people link these documents to each other: Pili-Yāma, Satturu/Šabbatāya, and Bānia/Amēl-Nanâ appear in BE 945 and EE 98, and Yāhû-natan is attested in BE 925 and $45 .{ }^{936}$ The population of Bìt-Gērāya was at least partially of Judean origin. In EE 98, which is the only document written in Bīt-Gērāya, almost every witness bears a West Semitic name or patronymic. The only exception is Bānia/Amēl-Nanâ, but, as shown above, Bānia was not an outsider but a man with close ties to Yadi-Yāma's family. West Semitic names are also well represented among Yadi-Yāma's co-lessees in BE 9 45, who, according to the document, appear to be people from Bìt-Gērāya. ${ }^{937}$ Bānia/Amēl-Nanâ is again the only person bearing both an Akkadian name and patronymic. Yahwistic names are well represented among the West Semitic onomasticon, both in EE 98 and in BE 945 .

It thus appears that Yadi-Yāma and Pili-Yāma were connected to the settlement of Bìt-Gērāya, which was inhabited by people of Judean and generally non-Babylonian origin, and which was insignificant enough to be very rarely mentioned in the Murašû archive. It was apparently a village located near the Urâti canal, as people from Bìt-Gērāya rented the canal in BE 945 , and the rental payment of the canal was to be delivered to the village (BE 925 ). The canal was important to the village, and the leases in BE 925 and EE 92 are to be seen in the context of BE 9 45. The roles of Yadi-Yāma, Yāhû-natan, and

933 On Ahīqam's brewing activities, see Section 4.3.6.3.

934 The idea that BE 925 and 45 reflect villagers' attempts to promote their own cause is proposed by van Driel 2002, 215.

935 van Driel, working notes.

936 The Nippurean witnesses of BE 925 and 45 are not taken into account here.

937 'PN1, PN2, ... PN9, and all their colleagues who are in Bīt-Gērāya'. 
Bānia/Amēl-Nanâ were as representatives, and they acted on behalf of the village community. While the large rents could only be met by a group of farmers, it was not practical or necessary for all the villagers to travel to Nippur to close deals.

Pili-Yāma had close connections to Yadi-Yāma and Bìt-Gērāya, but he was also in regular contact with the Murašûs and often present in Nippur. The most revealing document about his status is EE 26, in which he leases the Badiātu canal of Marduka, the same canal which was held or leased by Yadi-Yāma several years earlier. His two co-lessees were of non-Babylonian descent, and one of them was perhaps attested as a witness in BE 945 . The case bears resemblance to that of the Urâti canal, and it is reasonable to suggest that this derivative or part of the Badiātu canal was also of special importance to Yadi-Yāma, Pili-Yāma, and the community in Bìt-Gērāya. The Badiātu canal of Yadi-Yāma and Marduka cannot be geographically located in relation to Bīt-Gērāya, ${ }^{938}$ but it is hardly a coincidence that Yadi-Yāma and Pili-Yāma shared an interest in this canal. Moreover, Pili-Yāma's lease of the Badiātu canal of Marduka took place in 38 Art I or later, and as Yadi-Yāma is not attested after 36 Art I, there is a good chance that Pili-Yāma took over some communal responsibilities after Yadi-Yāma's death. This scenario also fits Yāhû-natan's lease of the Urâti canal in 40 Art I.

Despite the entrepreneurial features of Yadi-Yāma's and Pili-Yāma's transactions, they cannot simply be labelled as businessmen. ${ }^{939}$ Both men were Judeans, closely linked to the village of Bìt-Gērāya where they perhaps also resided. There is no reason to suppose that the community in Bìt-Gērāya was exclusively Judean, ${ }^{940}$ but it is evident that many of its inhabitants were of Judean origin. Surprisingly, bow lands, hațrus, or minor officials of the land-forservice sector are not referred to in the documents pertaining to Yadi-Yāma and Pili-Yāma. Therefore, these men were hardly officials, such as šaknu-type foremen of a hatru in the environs of Bìt-Gērāya, but influential members of the village community. ${ }^{941}$ In this function, they travelled to Nippur to represent the community and lease canal rights from the Murašu family. This does not exclude the possibility that their private interests are present in the documents

\footnotetext{
938 Zadok 1978a, 292 claims that the Badiātu of Yadi-Yāma and Marduka flowed through BìtGērāya. However, there is no evidence to support this claim. On the different watercourses named Badiātu, see Zadok 1978a, 288, 292, 314 .

939 On Pili-Yāma, see Cardascia 1951, 77.

940 Cf. Zadok 2002, 39, who identifies all Yadi-Yāma's partners in BE 945 as Judeans. See also his concept of Judean clans in the Nippur region in Zadok 1979a, 53-58.

941 Cf. Zadok 1979a, 58-59.
} 
as well. Pili-Yāma's debt of a kur.ra textile need not concern the economic interests of the people in Bīt-Gērāya, and Yadi-Yāma's brewing activities may have been very beneficial to him personally. As will be shown in the context of similar documents below, it is difficult to say if Yadi-Yāma's bìt ritti was held by him and his family alone or if he was its nominal holder on behalf of a larger community. Yadi-Yāma's and Pili-Yāma's earliest transactions show that the two men leased water and land to Enlil-šum-iddin and together with him. This was hardly possible without the backing of the rural community, although the responsibility rested nominally on a single man alone.

The size of the transactions pertaining to Yadi-Yāma and Pili-Yāma is very different from what we see in the documents from Yāhūdu and its surroundings. Ahīqam's largest transactions of over 5 minas of silver or 160 kurru of barley $\left(\mathrm{B}_{5}, 6 ; \mathrm{C}_{17}, 18\right)$ are of comparable size, but, in general, the transactions from the environs of Yāhūdu are significantly smaller. It is noteworthy that Ahīqam's largest transactions pertain to his business with the royal administration (B6; $\left.\mathrm{C}_{7}, 18\right)$ or dealings in Babylon (B5); accordingly, they do not relate to his interaction with farmers or small landholders. Texts pertaining to Ahīqam testify that he acted as an intermediary between farmers and the royal administration. Yadi-Yāma and Pili-Yāma occupied the same functional position in the administrative hierarchy of the land-for-service system. As representatives of the villagers of Bït-Gērāya, they acted as intermediaries between the farmers and the next level of hierarchy, the Murašu family or state administration. Private, communal, and official roles should not be seen mutually exclusive, and all three of the Judeans were in a position to benefit from their status of an intermediary.

\subsection{Judean Landholders and the Land-for-Service Sector}

\subsubsection{General Features}

The Murašû archive is held as the prime example of the land-for-service sector in Babylonia, but the documents pertaining to Yadi-Yāma and Pili-Yāma hardly touch upon this issue. No hatrus or bow lands are mentioned, and although Yadi-Yāma's bit ritti may not have been his private property, the term itself is not characteristic of the land-for-service sector. The Bīt-Gērāya dossier was written in 24-40 Art I, and it belongs to a less intensively documented phase of the Murašû archive. The dossier constitutes a distinct group, and none of its Judean protagonists is attested after 40 Art I.

The absence of certain terminology does not necessarily mean that YadiYāma, Pili-Yāma, and their colleagues in Bīt-Gērāya were not integrated into 
the land-for-service sector, but the reason may lie in the distribution of different text types in the Murašu archive. As discussed above, the majority of documents in the archive were written in 40 Art I - 7 Dar II, and especially mortgages are clustered in the last year of Artaxerxes I and the first year of Darius II. Receipts of rents and taxes paid by the Murašûs are also concentrated in 40 Art I - 7 Dar II. ${ }^{942}$ These are all document types which are not attested in the Bìt-Gērāya dossier but typically pertain to bow lands and other land properties managed by the Murašuss. ${ }^{943}$ On the contrary, leases of land and canals from the Murašûs are more evenly distributed over time. ${ }^{944}$ Because Judean holders of bow lands are attested after 40 Art I, it is likely that the invisibility of the land-for-service sector in the Bìt-Gērāya dossier results from the internal composition of the archive.

Eleven Judeans in seven different documents are attested as holders of bow lands in the Murašû archive. ${ }^{945}$ It is evident that 'bow land' does not simply refer to a plot that was held or cultivated by a single farmer: in six documents, bow lands are held nominally by at least two people, and four documents refer to an undetermined group of 'brothers' (šeš.meš; BE 10 118; EE 111) or 'lords of the bow land' ('íen.meš gišban; PBS 2/1 89, 218) as co-holders of these properties. ${ }^{946}$ This applies to the Murašû archive as a whole, and, in the promissory notes with real estate securities, bow lands are normally held by more than one person. ${ }^{947}$ This is not unattested in the environs of Yāhūdu either, where six documents refer to the co-ownership of a bow land. ${ }^{948}$ Inheritance divisions are often given as the reason for the co-ownership of bow lands, ${ }^{949}$ but this is not the entire picture, as co-holders also bore different patronymics and were thus presumably unrelated. ${ }^{950}$ There is also one example of a Judean holding a share in a horse land (UCP 9/3, 18-X-2 Dar II); I will discuss this important document in more detail below.

Like the number of co-holders, the size of bow lands varied considerably. In the Murašu archive, the debts secured with landholdings range between 10 and

942 Donbaz and Stolper 1997, 8.

943 On promissory notes with real estate as security, see Stolper 1985, 104-124; van Driel 1989, 223-224; Donbaz and Stolper 1997, 9-12. On receipts, see Cardascia 1951, 69-123.

944 Donbaz and Stolper 1997, 8.

945 BE $986 a$; BE 10 118; EE 111; PBS 2/1 27, 89, 185, 218. Note BE 10 33, which pertains to the same bow land as PBS $2 / 127$ and 89 , although the Judean co-landholder is not mentioned.

946 BE 9 86a refers to the lands of Rahìm-il and his sons.

947 Cardascia 1951, 29.

948 B2, 13; C15:15-16; 66, 69, 72.

949 Stolper 1985, 26; van Driel 1999, 219-220; Pearce and Wunsch 2014, 120.

950 B13; C69, 72; PBS 2/1 27, 89, 185. 
11,270 kurru of dates, ${ }^{951}$ and the security usually consists of a single bow land. ${ }^{952}$ Furthermore, the amount of rent in silver paid by the Murašus per bow land ranges between 3 and 60 shekels. ${ }^{953}$ As these payments have to be in some relation to the size of the respective landholdings, the variation in their size suggests a variation in the size of bow lands. ${ }^{954}$ A comparison with the data from the environs of Yāhūdu also attests to variation, but, surprisingly, the transactions are generally smaller than in the Murašû archive. The payments related to bow lands range from less than 1 kurru to 28 kurru of produce, the majority being smaller than 10 kurru.

A critical question regarding the functioning of the land-for-service system is the relationship between the size of a bow land and the number of its holders. If the scenario of successive inheritance divisions is right, most bow lands should have been split into tiny fragments by the late fifth century. As Judeans were settled in the Babylonian countryside soon after the deportations from Judah in the early sixth century, the holders of the bow lands in the Murašu archive must have belonged at least to the fifth or sixth generation. If a man held a hereditary bow land which was divided in equal parts and given to two sons in successive generations, his descendants in the fifth generation would only inherit a $1 / 16$ share of the bow land, or $1 / 32$ in the sixth generation. On the contrary, the available evidence shows that an average share in a bow land was still large enough to support a family. Based on his analysis of promissory notes with real estate securities, imittu rents, and leases of date gardens, Jursa concludes that the average share in a bow land in the Murašu archive roughly corresponded to the size of a plot held by a family in other Babylonian sources. ${ }^{955}$

As shares in bow lands were hereditary, ${ }^{956}$ it is reasonable to suggest that more royal lands were taken under cultivation as the rural population grew over time. The low cost of land and the prevalence of extensive arable farming suggest that land was readily available. ${ }^{957}$ This supports the commonly held view that one of the fundamental aims of the land-for-service system was to bring new lands under cultivation and royal control, and thus increase agricultural output and tax income. ${ }^{958}$

\footnotetext{
951 Cardascia 1951, 28; Jursa 2010a, 409.

952 Cardascia 1951, 36.

953 Stolper 1985, 147.

954 See Jursa 2010a, 409.

955 Jursa 2010a, 409-412.

956 Cardascia 1951, 29 n. 5; Stolper 1985, 25.

957 Stolper 1985, 125-134; Jursa 2010a, 417-418.

958 Stolper 1985, 99; van Driel 2002, 311-313; Jursa 2011a, 435.
} 
Even if a single plot was cultivated by a single family, the communal aspect of landholding is evident. Most bow lands were cultivated by several landholders, but only some of them often acted as representatives of the whole group, in the same vein as Yadi-Yāma and Pili-Yāma above. The use of representatives makes sense from a practical perspective: if a group of people shared the responsibilities related to a certain landholding, it was not necessary to record everybody's name on the document. As the majority of documents were written in Nippur while the landholdings were located in the countryside, it was good for the agrarian community if not everybody had to make the journey to the city. A clear example of the use of representatives is found in PBS $2 / 1218$, a receipt of sūtu rent paid by Rīmūt-Ninurta/Murašû concerning the bow land of Abī-Yāma/Šabbatāya, Zabad-Yāma, and 'all the other holders of their bow land' (lúen.meš gišban-šúu-nu gab-bi). At the end of the operative part of the document, Abi-Yāma takes responsibility for the whole group and guarantees that his colleagues (kinātātišu) will not contest the transaction. This phenomenon is reminiscent of the structure of the Yāhūdu imittu lists, in which a group of ten landholders is represented by one of their peers $\left(\mathrm{C}_{14}, 15\right)$.

The communal aspects of landholding are apparent in the texts pertaining to the three bit ritti lands (co-)held by Judeans in the Murašu archive. As argued above, Yadi-Yāma's leasing operations were closely related to certain canals and the community at Bìt-Gērāya, and, accordingly, it is possible that his bit ritti may actually be a property held by a larger group of people (BE 925,45$)$. Two other bìt rittis were held by two persons. Haggâ and Mattan-Yāma hold a bit ritti together in EE 24. In BE 9 3, Arad-Gula and Hanan-Yāma's bìt ritti is leased to five persons for sharecropping. This indicates that the size of the landholding was rather large and that there may have been other landholders in addition to Arad-Gula and Hanan-Yāma.

In order to place these observations in a larger context, it is necessary to examine the size of transactions pertaining to Judeans in the Murašû archive. Table 1 presents all transactions with quantifiable data: documents in which Judeans appear as debtors or lessees, documents in which the Murašûs cultivate land on behalf of Judean landholders, and documents in which Judeans appear as creditors or lessors. The table reveals that small transactions of no more than 10 kurru or 10 shekels - those typical to the tablets from the environs of Yāhūdu - are very rare in the documents pertaining to Judeans in the Murašu archive. Only two transactions (10\%) belong to this category. When the total size of the payment is divided by the number of obliged persons, the share of a single person remains above 10 kurru or 10 shekels in all but two cases. This emphasises a key difference between the texts from the environs of Yāhūdu and those from the Murašû archive: Ahīqar and Ahīqam dealt directly with 
TABLE 1 Transactions with quantifiable data pertaining to Judeans

Document Date $\quad \begin{aligned} & \text { Number of } \\ & \text { persons }^{a}\end{aligned}$ Amount $^{b} \begin{aligned} & \text { Amount } \\ & \text { per person }\end{aligned}$ Quality Type of document

1. Judeans among debtors or lessees

\begin{tabular}{|c|c|c|c|c|c|c|}
\hline BE 914 & 28-X-28 Art I & 2 & 97.28 & 48.64 & millet & $\begin{array}{l}\text { Receipt: rent } \\
\text { (canal and land) }\end{array}$ \\
\hline BE 925 & 17-I-31 Art I & 1 & 200 & 200 & barley & $\begin{array}{l}\text { Lease: canal and } \\
\text { land }\end{array}$ \\
\hline BE 945 & 20-V-36 Art I & $\begin{array}{l}9+ \\
\text { colleagues }\end{array}$ & 700 & $<77.78$ & barley & $\begin{array}{l}\text { Lease: canal and } \\
\text { land }\end{array}$ \\
\hline EE 94 & 26-V-37 Art I & 1 & 30 & 30 & silver & $\begin{array}{l}\text { Debt: kur.ra } \\
\text { textile, worth } 30 \\
\text { shekels of silver }\end{array}$ \\
\hline EE 26 & ?-?-38? Art I & 3 & $76+x$ & $?$ & produce & Lease: canal \\
\hline IMT 94 & 13-XII-40 Art I & 2 & 30 & 15 & silver & Debt \\
\hline BE $986 a$ & ?-III?-41 Art I & 2 & 2,761 & $1,380.5$ & produce & $\begin{array}{l}\text { Lease: land, } 72 \\
\text { oxen, } 18 \text { ploughs, } \\
\text { seed corn, barley } \\
\text { for wages }\end{array}$ \\
\hline EE 113 & ?-?-33+ Art I & 4 & $5^{0}$ & 12.5 & workers & $\begin{array}{l}\text { Contract: } \\
\text { payment of debt } \\
\text { by providing } \\
\text { labour }\end{array}$ \\
\hline EE 24 & ?-X-? Art I & 2 & $5^{0}$ & 25 & barley & $\begin{array}{l}\text { Lease: } 2 \text { oxen for } \\
5^{0} \text { kurru of barley }\end{array}$ \\
\hline EE 86 & 10+-?-Art I & 1 & 10 & 10 & barley & Debt \\
\hline $\begin{array}{l}\text { PBS } 2 / 1 \\
185\end{array}$ & 2-VII-1 Dar II & 3 & 70 & $23 \cdot 33$ & dates & Debt \\
\hline BE 1077 & 9-XI-3 Dar II & 1 & 2.5 & 2.5 & barley & Debt \\
\hline $\begin{array}{l}\text { PBS 2/1 } \\
89\end{array}$ & 28-IX-4 Dar II & 2 & $6 o$ & 30 & dates & $\begin{array}{l}\text { Debt: dates } \\
\text { instead of silver }\end{array}$ \\
\hline $\begin{array}{l}\text { PBS } 2 / 1 \\
208\end{array}$ & 25-VI-5 Dar II & $5(?)$ & 500 & 100 & fish & Lease: 5 nets \\
\hline $\begin{array}{l}\text { PBS } 2 / 1 \\
148\end{array}$ & $\begin{array}{l}\text { 25-VI-11 Dar } \\
\text { II }\end{array}$ & 1 & 276 & 276 & animals & $\begin{array}{l}\text { Lease: } 276 \text { sheep } \\
\text { and goats }\end{array}$ \\
\hline EE 89 & Dar II & 1 or more & 260 & $?$ & dates & Debt \\
\hline
\end{tabular}


TABLE 1 Transactions with quantifiable data pertaining to Judeans (cont.)

Document Date

Number of Amount Amount Quality

Type of document persons per person

2. The Murašûs cultivate land on behalf of Judean landholders

\begin{tabular}{|c|c|c|c|c|c|c|}
\hline $\begin{array}{l}\text { PBS } 2 / 1 \\
218\end{array}$ & $\begin{array}{l}\text { 26-VIII-6 Dar } \\
\text { II }\end{array}$ & $\begin{array}{l}2+ \\
\text { colleagues }\end{array}$ & $6 o$ & $<30$ & silver & Receipt: rent \\
\hline EE 34 & 4-VII-7 Dar II & 1 & 20 & 20 & silver & $\begin{array}{l}\text { Receipt: rent } \\
\text { (silver instead of } \\
\text { dates) }\end{array}$ \\
\hline \multicolumn{7}{|c|}{ 3. Judeans as creditors or lessors } \\
\hline $\mathrm{EE} 2$ & $5^{-\mathrm{V}-[24 \text { Art I }]}$ & 1 & 200 & 200 & produce & $\begin{array}{l}\text { Lease: canals and } \\
\text { land }\end{array}$ \\
\hline EE 98 & 20-IX-36 Art I & 1 & 70 & 70 & $\begin{array}{l}\text { vats of } \\
\text { beer }\end{array}$ & Debt \\
\hline
\end{tabular}

a 1. Number of debtors or lessees. 2. Number of landholders. 3. Number of creditors or lessors.

b The amount of dates, barley, millet, and other produce is given in kurrus and the amount of silver in shekels.

individual farmers and landholders, whereas the Murašûs more often operated with the representatives and foremen of larger communities of landholders.

\subsubsection{Hațru of the Sēpirus}

5.3.2.1 Haţrus in the Murašû Archive

As the land-for-service sector was designed to generate tax income and provide the state with a workforce and soldiers, the landholders and their holdings were attached to complex administrative structures. In Yāhūdu, the fields of Judean šušānus were eventually put under the supervision of the governor Uštanu, and several royal officials participated in their everyday administration through a long chain of command. The estates of royalty and high officials are also attested in the region. A similar picture emerges from the Murašû archive: landholdings were attached to estates of the crown, royalty, and high officials, and the governor Gübaru and his agents were also involved in the management of the land-for-service sector. ${ }^{959}$

959 On the administration of the land-for-service sector in the Murašû archive, see Stolper $1985,5^{2-103 .}$ 
In comparison to the environs of Yāhūdu, an important feature of late fifthcentury Nippur is the organisation of landholdings in administrative units called hațrus. ${ }^{960}$ More than sixty different hațus are attested in the Murašû archive, and their names generally refer to an administrative unit, such as the estate of the rab urâti ('the one in charge of horse teams'), or to professional and ethnic groups, such as the gate guards and the Carians. ${ }^{961}$ It is hard to believe that these designations were completely arbitrary, and, at least originally, they must have been related to the people attached to the hatru, to its function, or to its administrative affiliation. ${ }^{962}$ Names referring to the estates of the crown or high officials demonstrably reflect the submission of the given hatru, its landholders, and their holdings to the estate. ${ }^{963}$ In the case of ethnic designations of hatrus, the most logical reason behind these names is the assignment of deportees to hatrus according to their place of origin. ${ }^{964}$

However, the case of professional designations is more complicated. Despite the absence of a hatru of the Judeans, it is striking that all the bow and horse lands which were (co-)held by Judeans and which can be connected to a certain hațru belonged to a hatru of sēpirus (PBS 2/1 89, 218), sêpirus of the troops (uqu) (PBS 2/1 27; UCP 9/3), or sêpirus of the estate of the rab unqāti ('the one in charge of seals', PBS 2/1 185). In addition, a Judean is also attested as a co-holder of grain fields (zêru $\bar{u} \bar{\iota}$ šulpi) belonging to the hatru of the gardu ('dependent workers', BE 10 92), and another one served as the šaknu ('foreman') of the šušānus of the storehouse (nakkandu) in BE 1065 .

\subsubsection{Hatru of the Sépirus (of the Troops)}

Since Cardascia's and Stolper's studies, it has been well established that the designations hațru ša sēpirī, hațru ša sēpirī ša uqi, and hațar uqi refer to a single hatru. ${ }^{965}$ The professional designation sēpiru not only refers to scribes competent in Aramaic, but the available evidence shows that they also took care of administrative tasks. ${ }^{966}$ Accordingly, it would be tempting to argue that the evidence of hatrus of seppirus shows that a large number of Judean landholders were literate clerks in the state administration. However, although a number of

\footnotetext{
96o Stolper 1985, 70-103; van Driel 2002, 308-310.

961 Stolper $1985,72-79$.

962 See Stolper 1985, 72 .

963 Stolper $1985,54-55,89-93$.

964 Eph'al 1978, 80-83; Jursa 2011a, 435.

965 Cardascia 1951, 113; Stolper 1985, 76, 93-95.

966 Stolper 1985, 22; Pearce 1999; Jursa 2012; Bloch 2018.
} 
texts in the Murašu archive pertain to hațrus of sēpirus, ${ }^{967}$ none of them suggest that the holders of bow or horse lands actually worked as seppirus. As this matter is of prime importance for the present study, it will be discussed here in detail.

Three documents from the beginning of the reign of Darius II show that the hatrus of the sêpirus and the sêpirus of the troops were identical. ${ }^{968} \mathrm{~A}$ certain Bēl-Yadā/Mannu-kì-Nanâ, a Judean man called Aqbi-Yāma/Bāba-êțir, and their anonymous colleagues held a bow land belonging to the hatru of sēpirus in 28IX-4 Dar II (PBS 2/1 89). The bow land was located in Bìt-Ṣurrāya by the HarriPiqūdu canal, and it was under the supervision of a certain Nabû-mìt-uballiț. Their bow land was pledged to secure a debt of 6o kurru of dates, the equivalent of the taxes in silver which Rīmūt-Ninurta/Murašû had paid to their šaknu. Three years earlier, Bēl-Yadā and Aqbi-Yāma held half a bow land together with Nidinti-[Enlil] (PBS 2/1 27, 14-?-1 Dar II). ${ }^{969}$ Their land was at the disposal of Enlil-šum-iddin/Murašû, who paid taxes on their behalf to Nabû-mìt-uballiț/ Balāțu, the brother $(a h u)$ of Zabīn the šaknu of [...]. Here ahu is not a mere designation of a collegial relationship, for the two men were actually brothers. ${ }^{970}$ In another document (PBS 2/1 29) written on the same day before the same witnesses, Nabû-mit-uballit collects taxes on bow lands belonging to the hatru of the sēpirus of the troops. He is again described as the brother of Zabin, whose title is now fully preserved as the šaknu of the sêpirus of the troops. It becomes clear that the hatrus of the sêpirus and the sēpirus of the troops were identical, and that Zabīn and Nabû-mìt-uballit played a key role in the administration of this hatru.

Both Zabīn and Nabû-mìt-uballiț worked as šaknus in the hațru of the seppirus (of the troops) during the first years of Darius II. The evidence relating to Zabīn was discussed above, and his brother Nabû-mìt-uballit held the position in the first year of Darius II (BE 10 7, 2-I-1 Dar II). ${ }^{971}$ This document is

967 Ša sēpirī: BE 10 33, 37, 57; EE 82; PBS 2/1 3, 11, 89, 218. Ša sēpirǐ ša uqi: BE 10 102; P BS 2/1 (27), 29, 34, 66; UCP 9/3. Hațar uqi + šaknu ša sēpirī: BE 10 7. Ša sēpirī ša büt rab unqāti: IMT 5; PBS $2 / 1$ 185. Ša sêpirī ša büt rab ummu: РвS 2/1 196. These designations will be discussed below.

968 Augapfel 1917, 43-45; Cardascia 1951, 113-114; Stolper 1985, 83, 94.

969 Bēl-Yadā, Nidinti-Enlil, and their anonymous colleagues of the hațru of the sêpirus are also attested in BE 1033 (27-IV-1 Dar II). The text pertains to the same bow land in BìtȘurrāya by the Harri-Piqūdu. The land was pledged to Enlil-šum-iddin to secure the debt of $287 ; 3$ kurru of dates. This document is a good example of the legal and scribal practices in the archive: although Aqbi-Yāma must have been among the landholders, his name is this time lumped together with other anonymous colleagues.

970 BE 10102 gives Zabīn's patronymic, Balāțu. See Stolper 1985, 83.

971 See Stolper 1985, 83, 85, 93-94. 
peculiar, as it refers to the administrative unit as the hatru of the troops ( $h a-t a-$ riú-qu), but Nabû-mìt-uballit bears the title of the šaknu of the sēpirus. ${ }^{972}$ The titles held by the two brothers were apparently quite flexible, because Nabûmìt-uballit is also titled as the deputy (šanû) of Zabīn the šaknu in the same year (PBS 2/1 34, ?-?-1 Dar II ). In the following years, Nabû-mìt-uballit no longer has the title of šaknu, but he appears in a šaknu-like function in PBS 2/1 89 (28IX-4 Dar II), in which the hatru of the seppirus is said to be under his management (šá ina šu $\left.{ }^{\mathrm{II}}\right) \cdot{ }^{973}$ As Stolper has shown, there is a lot of flexibility in the tenure of a šaknu, and it is possible that two šaknus had overlapping periods of service in the same hatru. ${ }^{974}$ Judging by the available evidence, it appears that both Zabīn and Nabû-mìt-uballit were strongly involved in the management of the same hatru, although there was considerable variation in their titles.

The evidence discussed thus far confirms that the hatru managed by Zabin and Nabû-mìt-uballit was known by three names: hațru of the sēpirus, hațru of the sêpirus of the troops, and hatru of the troops. This variance is not a result of different scribes favouring different names, because a single scribe, Ninurtaab-ușur/Enlil-šum-iddin, wrote the great majority of tablets pertaining to this hatru and used all three designations. ${ }^{975}$ From now on, I use the name 'hatru of the sēpirus of the troops' to refer to this unit. The designation 'hatru of the troops' is attested only in BE 10 7:3 and might be a scribal mistake. ${ }^{976}$

\subsubsection{Hatrus and High-Ranking Sēpirus}

In addition to the three names discussed above, there are two other hatru names that refer to sēpirus. The first, hațru ša sēpirī ša bit rab unqāti, is attested in IMT 5 (18-VI-40 Art I) and PBS 2/1 185 (2-VII-1 Dar II).977 The name refers to the estate of the rab unqa $\bar{t} i$ ('the one in charge of seals'), a high official in Babylonia who is attested in the Neo-Babylonian and Persian periods. His exact duties are unknown, but it is likely that he belonged to the king's retinue. ${ }^{978}$ Apart

972 Cardascia $(1951,113)$ and Stolper $(1985,93)$ discuss BE 107 , but they mistakenly claim that the document refers to the hatru of the sêpirus of the troops.

973 Stolper 1985,85 , argues that he was the šaknu at this time.

974 Stolper $1985,83-88$.

$975 \mathrm{BE} 10$ 7, 33, 37, 102; PBS 2/13, 27, 29, 66, 89, 218; UCP 9/3. In addition, three documents (IMT 5; PBS $2 / 1185,196)$ are special cases and they will be discussed below.

976 However, note that Nabû-mit-uballiț's title on the following line is simply 'the šaknu of the sēpirus'.

977 On the correct reading of PBS 2/1 185, see Donbaz and Stolper 1993, 1997, 82. CAD U-W, 203 should be corrected accordingly.

978 See Donbaz and Stolper 1997, 82. The rab unqäti's close connection to the king is suggested by BIN 122 ; YOS 6 10, 11. On the two latter documents, see Frame 1991, 54-61. 
from the two texts discussed below, the rab unqa $\bar{t} i$ is not attested in any other texts of the Murašû archive.

According to PBS 2/1 185, two Judean men, Abī-Yāma/Šabbatāya and Hannān/Hanan-Yāma, and a certain Bēl-ittannu/Qiš-ga-a belonged to the hațru of the sêpirus of the rab unqāti's estate and held a bow land which was located in Bīt-Erībâ by the Harri-Piqūdu canal. The bow land was pledged to Enlil-šum-iddin's son Murašû to secure a debt of 70 kurru of dates. ${ }^{979}$ Five years later, Abī-Yāma/Šabbatāya held a bow land together with a Judean named Zabad-Yāma and their colleagues in Bīt-Šalāmē by the Harri-Piqūdu canal (PBS 2/1 218, 26-VIII-6 Dar II). The bow land belonged to the hatru of the sêpirus of the troops and was at the disposal of Rīmūt-Ninurta, who paid the sūtu rent of 1 mina of silver to Abī-Yāma. It appears that the documents refer to two different bow lands, but it is surprising that a person named Abī-Yāma/Šabbatāya appears as a co-holder of both of them. There are no other attestations of the name Abì-Yâma in the Murašû archive. It is also an important observation that the names of the two hatrus resemble each other and that both bow lands were located by the Harri-Piqūdu canal, by which some other landholdings of the hatru of the seppirus of the troops lay. ${ }^{980}$ These observations suggest some connection between the two hatrus. IMT 5 adds little to this discussion, but it shows that a certain Lâbâši/Nabû-ittannu and his colleagues held land belonging to the sêpirus of the rab unqāti's estate. The plot was located in Tilhurdi, which lay at the junction of the Sîn and Enlil canals. ${ }^{981}$

Neither Iмт 5 nor Р BS $2 / 1185$ refer to the šaknu of the sêpirus of the rab unqāti's estate, but the latter document reveals that the hatru was under the management of a certain Mannukiya. The name (spelled Man-ki-ia or Man$n u-k i-i a)$ is very rare in the Murašu archive, with only one man having it. He was a servant $(a r d u)$ of Prince Manuštānu in the late reign of Artaxerxes I, 982 and, after the accession of Darius II and the defeat and death of Manuštānu, ${ }^{983}$ he served as a sêpiru of Gūbaru, the governor of Akkad. ${ }^{984}$ His father Paqiqi probably served Gūbaru as well and acted as a šaknu in the hațru of the

979 On Murašû/Enlil-šum-iddin, see Cardascia 1951, 10; Stolper 1985, 20.

$980 \quad$ BE 107,33 ; PBS 2/1 3, 89 .

981 On Til-hurdi, see Zadok 1978a, 289, 291, 306; 1985, 310-311, 370.

982 TuM 2-3 180 (40 Art I); BE 984 (41 Art I). EE 56 is a broken text which refers both to Manuštānu and to Mannukiya (20+ Art I).

983 Stolper 1985, 90-92; Briant 2002, 588-589.

984 IMT 46 (text: 5 Dar II, but emendated by Stolper 1992, $71+$ n. 10 as 6 Dar II ); PBS 2/1 100+ (6 Dar II; edited in Stolper 1992, 75-76); BE 10118 (7 Dar II). In these texts, he is always attested together with Iqī̌sa, another sēpiru of Gūbaru. He is probably attested with Iqī̌sa 
sword-bearers (BE 10 84, 85, both 4 Dar II). ${ }^{985}$ Mannukiya's career is an example of administrative continuity in a period of political turbulence. Stolper has noted that some of Manuštānu's holdings and servants were transferred to a certain Artahšar after the accession of Darius II, ${ }^{986}$ and the case of Mannukiya and Gūbaru was clearly the same.

Mannukiya was a man of importance, emphasised by the fact that he visited Susa together with Rīmūt-Ninurta and other people from Babylonia at the end of Darius II's sixth year. ${ }^{987}$ The visits of Babylonian businessmen and officials to Susa were related to taxation, ${ }^{988}$ and Mannukiya's role as a seppiru of the governor, supervisor of a hatru, and witness of tax-related transactions (EE 56; TuM 2-3 180) fits this pattern perfectly. ${ }^{989}$ Moreover, his servants received a payment for transporting barley used for flour from Nippur to the Kabaru canal, which was the principal waterway connecting Babylonia to Susa. ${ }^{990}$ In addition to managing tax flows from the Nippur region, Mannukiya's local importance in Nippur is underlined by a legal case involving property worth 30 minas of silver, which he witnessed together with other officials (BE 10 118). It must be noted that not all sêpirus in the archive exercised such power, but most of them were literate clerks employed by royal officials or businessmen. ${ }^{991}$

The hatru of the seppirus of the troops was also managed by a high-ranking sēpiru. ${ }^{992}$ A certain Abì-ul-īde, who is in charge of the hațru in PBS 2/1 3, is most likely Abì-ul-īde the sēpiru in BE 105 and PBS 2/1 173. Abī-ul-īde was not a low-ranking clerk but superior to the minor officials of the hatru (PBS 2/1 3) and the master of a number of servants (PBS 2/1 173). He also authorised tax collection in the hatru of the sword-bearers of the crown prince's estate (BE 10 5), which connects him to Mannukiya's father, who supervised the same hatru.993

in EE 111 ( 7 Dar II?) as well; the text is closely related to BE 10 118. On Gūbaru, see Stolper 1987, 396-398; 1989, 290-291.

985 TuM 2-3 180 reveals Mannukiya's patronymic, and it is plausible that the homonymous individual in BE 1084 and 85 is his father. See Zadok 2015a, 117.

986 Stolper 1985, 91-92. See Section 5.4.

987 IMT 46; PBS 2/1 100+. See Stolper 1992; Waerzeggers 2010b, 784-785.

988 Waerzeggers 2010b, esp. 797-809.

989 Cf. Bloch 2018, 302-317.

990 BE 984 (see Stolper 1990, 167; Waerzeggers 2010b, 807 n. 111). On the Kabaru canal and tax deliveries to Susa, see Waerzeggers 2010b, 790, 804-807; Tolini 2011 vol. 1, 491-498.

991 Cardascia 1951, 15; Stolper 1985, 22.

992 Stolper 1985, 93-94.

993 On the hatru of the sword-bearers (of the crown prince's estate), see Stolper 1985, 54-55, 76 . 
Abì-ul-īde appears in PBS 2/1 3 together with a man named Șihā, who is perhaps identical with Ṣihā the ahšadrapānu ('satrap') in PBS 2/1 2.994 In addition to Abì-ul-īde and Șihā, two other men, Patēšu and Ispitāma', had authority over the hatru of the sēpirus of the troops in the first year of Darius II. ${ }^{995}$ Their titles are not given in any text, but they appear to be men of high rank. Ispitāma? was perhaps the son of Patěšu, and he is attested as a member of the jury in a legal case from the accession year of Darius II (IMT 105) ${ }^{996}$ and perhaps as a landholder in the environs of Babylon or Borsippa in a text from the Kasr archive (unpublished YвC 11562). ${ }^{997}$

It is hardly a coincidence that both Mannukiya and Abì-ul-īde were sēpirus. Although the offices held by Ṣihā, Patēšu, and Ispitāma? remain uncertain, it is reasonable to suggest that the sêpirus who are referred to in the names of some hatrus were officials of high rank and beneficiaries of the landholdings, not the people who cultivated the fields, paid taxes, and performed military service. ${ }^{998}$

Mannukiya also helps to establish a link between the sêpirus of the rab unqāti's estate and Zabīn, the šaknu of the hatru of the sêpirus of the troops. The two men appear in a document of litigation in Nippur in 13-I-7 Dar II (BE 10 118): only the seal of Zabīn/Balāțu and the accompanying caption have been preserved, but he was most probably among the witnesses of the document. He bears here an exceptional title, didakku, an Iranian loanword based on *didi-ka ('supervisor'). ${ }^{999}$ This is the only attestation of didakku in Babylonian sources, and it likely renders his usual title šaknu. Mannukiya is listed among the witnesses together with Iqiša, his frequent companion and a sēpiru of Gūbaru. ${ }^{1000}$ Their official titles are not preserved in the document, but another document related to the same litigation (EE 111) features Iqī̌sa, the sēpiru of Gübaru, and thus confirms the identification. In light of these documents, it appears more and more unlikely that the hațru of the sēpirus of the troops and the hațru of the sēpirus of the rab unqāti's estate were unrelated.

994 Stolper 1985, 94. See also Jursa and Stolper 2007, 264-265, 269-270. The title ahšadrapānu does not necessarily refer to a satrap (governor) of a province (Jursa and Stolper 2007, 264).

995 Patēšu: BE 1033 (27-IV-1 Dar II ); BE 1037 (2-V-1 Dar II). Ispitāma?': PBS 2/1 27, 29 (both 14-?-1 Dar II). See Stolper 1985, 94-95.

996 On their possible consanguinity and identification with Petisas and Spitames in Ctesias' Persica, see Stolper 1985, 94 + n. 100; Dandamayev 1992b, 88, 112; Donbaz and Stolper 1997, 153 .

997 Stolper 1987, 395, 400 .

998 Stolper 2001, 106 seems to suggest this as well.

999 Tavernier 2007, 419-420. See also CAD D, 135.

1000 See above. 
There is yet another administrative designation pertaining to seepirus, namely, the šaknu of the sēpirus of the rab ummu's estate. A certain Lâbâši/MušēzibBèl, who held this title in the third year of Darius II (PBS 2/1 196, 28-VI-3 Dar II), was in charge of a bow land in the village of Bannēšu ${ }^{1001}$ by the Namgardūr-Enlil canal. The word hatru does not occur in this document, but there is no doubt that the text concerns a similar administrative unit. The rab ummu was a Babylonian official, but, as is the case of the rab unqāti, his concrete duties are mostly unknown. ${ }^{1002}$ A text from the Ebabbar archive (BM 64707) $)^{1003}$ and the rab ummu's seal impression with a military scene (Stolper 2001 no. 9) may imply that he had a military function, and Stolper proposes that the word ummu in his title may mean 'quiver'1004 However, this remains speculative in the absence of further evidence. ${ }^{1005}$ The title rab ummu is attested in several texts from the Murašû archive, and one holder of this title, Mīnu-ana-Bēl-dān/ Tahhūa, is known by name. ${ }^{1006}$

Mīnu-ana-Bēl-dān the rab ummu can also be connected to the sēpirus of the governor Gūbaru. He witnessed a large tax payment of 15 minas of silver in Nippur together with Tattannu/Aplâ the simmagir and Bēl-ab-uṣur/ Bēl-abușur, the sêpiru of the governor Gūbaru (BE 10 101, 18-VII-5 Dar II). The career of Bēl-ab-ușur was perhaps similar to that of Mannukiya, who first served Prince Manuštānu and later the governor Gūbaru. In 29-III-40 Art I, a certain Bēl-ab-uṣur/Bēl-[...] the brewer ("'ísiraš), another brewer, and a mār [bīti?] of Manuštānu received a sūtu payment of 40 kurru of kasû by the written order of Manuštānu (IMT 40). As the lower left horizontal wedge of the ad sign and the upper right Winkelhaken of the ùru sign seem to be preserved, reconstructing Bēl-ab-ușur's patronymic as Bēl-ab-ușur is likely. ${ }^{1007}$ Given the delivery of kasû, a plant commonly used in brewing, ${ }^{1008}$ Bēl-ab-uṣur was obviously a brewer of some sort. However, he was not necessarily involved in the actual brewing process; he could perhaps have been a foreman of a brewery held by Manuštānu. ${ }^{1009}$ In the early years of Darius II, Bēl-ab-ușur/Bēl-ab-uṣur is attested in three

\footnotetext{
1001 'The town of Caria', apparently a settlement of Carian deportees or mercenaries. See Zadok $1985,64-65$.

1002 MacGinnis 1998; Stolper 2001, 103-111; CAD U-W, 133.

1003 Published in MacGinnis 1998.

1004 Stolper 2001, 107.

1005 See Stolper 2001, 106-107; cf. MacGinnis 1998, 180.

1006 The title rab ummu is attested in the following Murašû texts: BE 9 72; BE 10 101; PBS 2/1 175, 196, 207. Mīnu-ana-Bēl-dān is attested in BE 10 101; PBS 2/1 207 (his servant witnesses); and in a non-Murašû text edited in Stolper 2001 (no. 9).

1007 Cautiously suggested by the editors of the text as well.

1008 Stol 1994, 175-179.

1009 Personal communication with Caroline Waerzeggers.
} 
documents in addition to BE $10101 .{ }^{1010}$ All four documents pertain to the same individual, which is confirmed by the identical seal impressions accompanying his name. ${ }^{1011}$ One of these documents is BE 10118 , which I already discussed above: Bēl-ab-uṣur appears as a witness together with Zabīn and Mannukiya. Moreover, Bēl-ab-uṣur also knew the brother of Zabīn. Bēl-ab-uṣur, Tattannu the simmagir, and Nabû-mìt-uballiț/Balāțu appear among the witnesses of a sūtu payment in 25?-XI-3 Dar II (PBS 2/1 72). Although Nabû-mìt-uballiț's seal is different from the one he used in other documents, ${ }^{1012}$ his rare name makes it very likely that he was the Nabû-mit-uballit of the hațru of the sêpirus of the troops. ${ }^{1013}$

\subsubsection{Conclusion}

A careful reading of the texts pertaining to the hatru of the sêpirus of the troops, sêpirus of the rab unqāti's estate, and sêpirus of the rab ummu's estate reveals close connections between the officials in charge of these holdings. At the same time, it becomes clear that the administrative structures in the landfor-service sector were complex and several people of higher and lower statuses participated in the management of landholdings and their taxation. Two brothers, Zabīn and Nabû-mit-uballit, took care of the everyday affairs of the hatru of the sêpirus of the troops, but three different men - Abì-ul-ìde, Patēšu, and Ispitāma ${ }^{\text {? }}$ - figure as their superiors in the first year of Darius II. At the same time, Mannukiya managed the hațru of the sêpirus of the rab unqāti's estate. Other documents reveal that both Abì-ul-īde and Mannukiya were sēpirus, but not mere alphabetic scribes.

The career of Mannukiya is especially noteworthy: he first served Prince Manuštānu and later the governor Gūbaru, and he travelled to Susa in his role as an official in charge of tax flows from Babylonia. He also knew Zabīn and another sēpiru of Gūbaru, Bēl-ab-uṣur. In his turn, Bēl-ab-uṣur was in contact with both Zabīn and Nabû-mìt-uballit, and he witnessed an important transaction with Mīnu-ana-Bēl-dān, the rab ummu. Accordingly, the people managing the three hațrus of seepirus were closely connected. Moreover, Abī-Yāma/ Šabbatāya was obviously a landholder in the hațus of the sêpirus of the troops and the sēpirus of the rab unqāti's estate.

The case of Abì-ul-ide and Mannukiya suggests that the holders of bow lands in these three hatrus were not sēpirus themselves but subordinates of

1010 BE 10 118; PBS 2/1 72, 224.

1011 Bregstein 1993 no. 173.

1012 Compare Bregstein 1993 no. 38 to no. 27.

1013 Bregstein 1993, 430 makes the same identification. 
high-ranking sēpirus. In other words, one should not perceive the petty landholders as literate sēpirus but common farmer-soldiers. ${ }^{1014}$ This argument is corroborated by the unique text UCP 9/3 (18-X-2 Dar II ), in which Gadal-Yāma/ Rahīm-il agrees with Rīmūt-Ninurta to perform the service obligations attached to a horse land. ${ }^{1015}$ It appears that Gadal-Yāma's father had adopted Rīmūt-Ninurta's uncle Enlil-šum-iddin, which allowed the Murašûs to have a share in Rahim-il's horse land. ${ }^{1016}$ The official in charge of the call-up was Zabinn, the šaknu of the hatru of the sēpirus of the troops, which reveals that the horse land belonged to this administrative unit. Gadal-Yāma was to be equipped with a horse, weapons, clothing, and travel provisions, and then he would travel to Uruk.

It is evident that Gadal-Yāma was supposed to perform military service as a horseman, and he was not the only soldier travelling to Uruk at this time. Six other documents from the Murašu archive show that holders of bow lands in the Nippur region were obliged to send soldiers to Uruk in the tenth month of the second year of Darius II. ${ }^{1017}$ The terminology employed in the texts makes it very clear that people were fitted out as soldiers and were sent to Uruk to perform actual service. Although external sources do not shed light on the circumstances which led to the mustering of troops at this precise moment - if the call-up was not annual ${ }^{1018}$ - the documents emphasise the fact that the military and service obligations attached to bow and horse lands were not fictional. As there is no military rationale to send an educated scribe or clerk to serve as a soldier, Gadal-Yāma, a member of the family who held the horse land, was hardly a sêpiru. The document is the only piece of evidence showing that Judeans also held shares in horse lands.

The previous investigation has revealed that the sêpirus who lent their titles to the pertinent hatrus were not subordinates of these units but high officials

1014 Cf. Bloch 2018, 317-331, 380-397.

1015 This document has been discussed in several studies. See Lutz 1928; Cardascia 1951, 179182; Ebeling 1952; Zadok 1979a, 66-67; Stolper 2001, 120-127; van Driel 2002, 235-236; Manning 2016; Bloch 2018, 326-331.

1016 See Cardascia 1951, 179-182; Joannès 1995, 1481. The clause about the adoption is difficult as it refers to Barīk-il's share, which Rahīm-il had given to Enlil-šum-iddin. Some commentators have judged that Barìk-il was Rahīm-il's (step-)father (Lutz 1928, 269; Zadok 1979a, 66-67; 2002, 40), but EE 35 suggests that Barik-il was Rahīm-il's son and thus GadalYāma's brother (see my discussion in Section 5.3.3 below).

1017 BE 10 61, 62; PBS 2/1 54, 162, 194; IMT 83. EE 117 is badly broken but may belong to this group as well. The texts were written between the eighteenth and twenty-fourth day of the tenth month. See Augapfel 1917, 17-18; Cardascia 1951, 40, 99; Joannès 1982a, 17-20; Stolper 1985, 123 + n. 46; 2001, 124 n. 53; Briant 2002, 598-599.

1018 See Stolper 1985, 123; Briant 2002, 598-599. 
in the Nippur region. They were servants of the governor of Akkad, and they witnessed documents together with other high officials such as the simmagir and the rab ummu. It would probably be more accurate to speak of only a single hatru, because the different designations discussed above may all refer to the same administrative unit. ${ }^{1019}$ This suggestion is supported by the following factors: first, there was significant linkage between the officials in charge of the various hatrus of sēpirus. Second, the example of the hatru of the sēpirus of the troops demonstrates that the names of hatrus were very flexible. Third, the bow lands held by Judeans were concentrated in these hatrus. Finally, AbīYāma/Šabbatāya held plots in the hațrus of the sēpirus of the troops and the sēpirus of the rab unqäti's estate.

A number of people and institutions were supervisors and beneficiaries of the hatru, among them the sêpirus, the rab ummu, the rab unqa ti, their estates, the governor of Akkad, and, eventually, the king. Like in the environs of Yāhūdu, the highest official in this administrative hierarchy was a governor, in this case Gūbaru. His seepirus, high officials in the Nippur region, supervised the landholdings and tax flows together with the staff of the rab ummu's and rab unqāti's estates. This structure also resembles the situation in the surroundings of Yāhūdu, where the deputy of the rab urâti was in charge of the governor's lands. This picture is in line with Stolper's observations about the administration of other landholding units in the Nippur countryside. ${ }^{1020}$ Judean landholders in the hatru were not sēpirus themselves but farmers who had to perform actual military service for the state.

\subsubsection{Large-Scale Landholding: Rahìm-il and His Family}

Not all Judean landholders in the land-for-service sector farmed a modest plot of land. Some had significantly larger holdings. An important example is Rahīm-il, who together with his family held several plots, including a horse land, in the Nippur region. ${ }^{1021}$ At least some of Rahim-il's landholdings belonged to the hațru of the sēpirus: Gadal-Yāma, who was discussed above in the context of his trip to Uruk to perform military service, was Rahìm-il's son (UCP 9/3). The family is attested in eleven documents from the thirty-third year of Artaxerxes I until the fifth year of Darius II. Figure 10 presents their family tree.

1019 Stolper 1985, 76 and Bregstein 1993, 648 suggest that there was some connection between the hatru of the seppirus of the troops and the hațru of the seppirus of the rab ummu's estate.

1020 Stolper 1985, 48-49, 54-55, 88 + n. 70, 89-96, 100-103.

1021 Some aspects of this family's activities are briefly discussed by Zadok 1979a, 54, 64-67; 2002, 38-40. He accepts fewer people as members of this family than I do. 


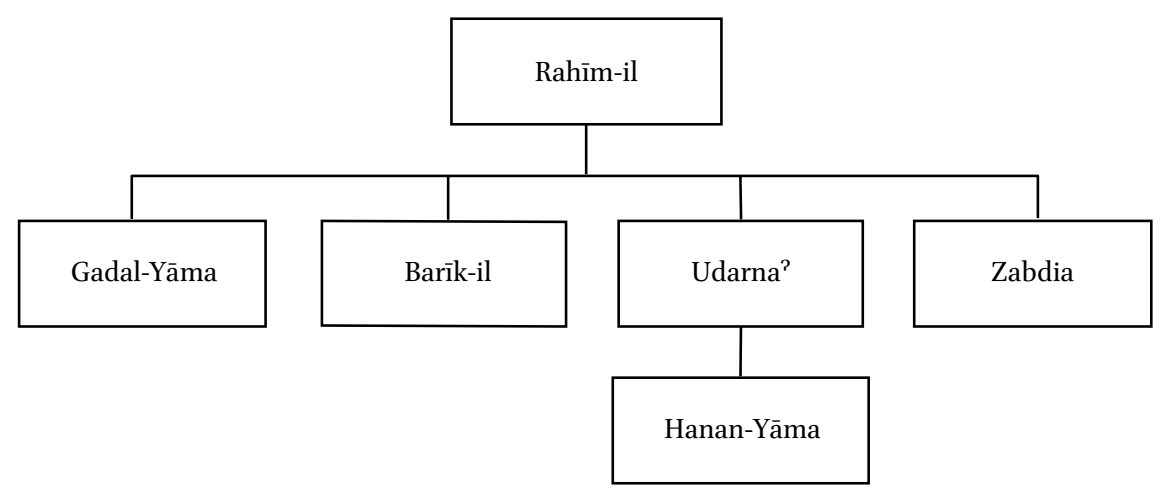

FIGURE 10 The descendants of Rahīm-il

The earliest document pertaining to the family is EE 35 (17-I-[33] Art I), a receipt of a sūtu payment in silver from Barìk-il/Rahīm-il to Munnātu/Umahparê. The amount of silver is broken and the juridical status of the pertinent landholding remains unclear. Munnātu/Umahparê, the recipient of the rental payment, was probably a royal official, judging by his Iranian name and Egyptian patronymic. ${ }^{1022}$ Udarna', a brother of Barik-il, witnessed the transaction.

Udarna"s Iranian name ${ }^{1023}$ betrays his father's familiarity with the onomasticon of the foreign elite, which most likely resulted from regular contact with the officials in the land-for-service sector. This view is supported by two documents which Udarna ${ }^{2}$ witnessed in the following years. The first one pertains to Enlil-šum-iddin's leasing of land for thirty years from Halabesu/ Paț-Esu and Halabesu/Mukēšu (IMT 3, 8-XI-34 Art I), and the second one to Enlil-šum-iddin's sūtu rent payment to Mitrēn, a servant of the mašennu official Tattannu (BE 9 59, ?-?-37 Art I). Mitrēn's name is Iranian, ${ }^{1024}$ and Halabesu's Egyptian patronymic Pat-Esu ${ }^{1025}$ suggests that he was connected to the royal administration.

The life of the family was affected by distrust and tension between the brothers. In the thirty-ninth year of Artaxerxes I, Udarna? addressed Enlil-šumiddin at the assembly (puhru) of Nippur, claiming that Enlil-šum-iddin's servants and agents together with Udarna"s brother Zabdia and a certain Bēlittannu, had come to Udarna"'s house and taken his property illegally (BE 969 ,

1022 Munnātu: Tavernier 2007, 337; Umahparê: Zadok 1989-1990, 274; Hackl and Jursa 2015, 179.

1023 Tavernier 2007, 65 .

1024 Tavernier 2007, 250.

1025 Mattila 2004; Hackl and Jursa 2015, 178. 
4-XII-39 Art I). ${ }^{1026}$ The nature and value of the property is not specified, but the accusation was apparently well founded, as Enlil-šum-iddin had to return the property to Udarna?. The litigation was witnessed by Udarna?'s son HananYāma, and both the father and son impressed their cylinder seals on the tablet. ${ }^{1027}$ The fact that they possessed such objects implies that they needed them regularly.

The extensive size of Rahīm-il's landholdings becomes apparent in BE 9 86a (?-?-[41] Art I). This document is a lease of several plots of land from Enlil-šumiddin to his slave Ea-zittišu/Ahdatuše and a certain $[G] a-d a-a l^{-}{ }^{2}-a /$ Šabbatāya. The leased lands consist of the holdings of Enlil-šum-iddin and two bow lands of Rahīm-il and his sons ('ra-hi-im-dingir.meš $u$ dumu.meš-šú). Rahīm-il's bow lands must have been vast, as one holding was located in Til-Gabbāri, Bīt-ilšakā, Til-Rahīmu, and the environs (limìtu) of Til-Gabbāri, and the other in Titurru ša simmagir, Hușșēti ša [rēêêe],1028 Išqallūnu, Bīt-Kikī, Bīt-Akkē, and extending onto both sides of the Simmagir canal. In addition to these lands, 72 oxen, 18 ploughs, seed corn, and barley for the wages of workmen were included in the three-year lease, the annual rent of which was 2,700 kurru of produce and additional payments.

A reference to the bow lands of Rahìm-il and his sons in BE 9 86a would not alone confirm that the Rahim-il in question is identical with the Judean man discussed in this section. However, $[G] a-d a-a l^{-}{ }^{2}-a / S ̌$ sabbatayya, the lessee of the lands in BE $986 \mathrm{a}$, can be connected to the Judean family. First, there was a close relationship between a certain Gadal-Yāma/Šabbatāya and the family of Rahīm-il. Hanan-Yāma/Udarna? and Gadal-Yāma/Šabbatāya together witnessed two documents, the litigation document BE 969 and BE 107 (2-I-1 Dar II), a receipt of tax payment from horse and bow lands belonging to the hatru of the sēpirus of the troops. Second, $\mathrm{Ga}-\mathrm{da}-a \mathrm{l}^{2}-\mathrm{a}$ is a hypocoristic writing of Gadal-Yāma. A similar writing of the name Gadal-Yāma is attested in EE 65 (20?-VI-[41 Art I]), in which a seal caption naming a certain Ga-da-al-ia is preserved on a partially illegible tablet. The same cylinder seal is attested in UCP $9 / 3$, in which the seal user's name is Gadal-Yāma. ${ }^{1029}$ We may conclude that $[G] a-d a-a l-{ }^{2}-a / S ̌$ Sabbatāya in BE 9 86a was identical with Gadal-Yāma/Šabbatāya

\footnotetext{
1026 Zabdia, son of Rahīm-il, is also attested as a witness to Enlil-šum-iddin's transaction in BE $965(28-?-38$ Art I ).

1027 Udarna?: Bregstein 1993 no. 362. A lion attacks a prey, perhaps a bull or boar. Hanan-Yāma: Bregstein 1993 no. 108. The Babylonian hero subjugates a bull, and the crescent moon hovers above them.

1028 The emendation is suggested by Augapfel 1917, 66; Zadok 1985, 176 .

1029 Bregstein 1993 no. 16. The Persian hero holds two lions in his hands.
} 
in BE 969 and BE 10 7, and, furthermore, that the landholder Rahim-il in BE 9 $86 \mathrm{a}$ is the Judean man discussed in this section.

It becomes apparent that Rahìm-il was not a subsistence farmer cultivating a small plot with his family but a significant landholder in the land-for-service sector. The same picture emerges from UCP $9 / 3$, which concerns the horse land of Rahīm-il. His son Gadal-Yāma travelled to Uruk to perform the military service incumbent on the holder of the horse land. This Rahim-il is most likely identical with the Rahīm-il discussed in this section, as, according to the text, he had given Barik-il's share in the horse land to Enlil-šum-iddin by means of a fictional adoption. Our Rahīm-il had a son named Barīk-il as well, and the document fits the picture of a family that was a significant landholder in the Nippur region but suffered from financial difficulties in the late reign of Artaxerxes I. During that difficult period - perhaps related to the accession wars after Artaxerxes' death - Enlil-šum-iddin was able to interfere with the family property. The fictional adoption of Enlil-šum-iddin was obviously a way to transfer part of the horse land to the Murašûs and perhaps settle some outstanding claims (UCP 9/3). ${ }^{1030}$ Similarly, some bow lands of the family had come into the disposal of Enlil-šum-iddin, possibly via a lease or as pledged property (BE 9 86a). Finally, the tensions between Enlil-šum-iddin and Rahīm-il's family are betrayed by the litigation over Udarna"s stolen property (BE 969 ).

Despite its difficulties, the family did not disappear from the scene after the accession of Darius II, and Hanan-Yāma is attested twice as a witness in the fourth and fifth years of the king (BE 10 84; PBS 2/1 107). It is noteworthy that he impressed a different seal on the later document, compared to BE 969 seven years before. ${ }^{1031}$ Ownership of seals was very common in this family, as Udarna ${ }^{\text {? }}$ Hanan-Yāma, and Gadal-Yāmaa ${ }^{1032}$ all impressed their seals on one or more documents in the archive. This is suggestive of the high socio-economic status of the family. An interesting feature of the seals is their imagery, which always employs the motif of a bull or lion. This may tell something about the preferences of the family, because these motifs were not otherwise favoured by Judean seal owners. ${ }^{1033}$

The texts pertaining to Rahīm-il and his descendants constitute an exceptionally informative group about an important Judean family in the Nippur region. The family had several large landholdings in the land-for-service sector,

\footnotetext{
1030 See Cardascia 1951, 181-182.

1031 Bregstein 1993 no. 268. The seal depicts a bull.

1032 Bregstein 1993 no. 16. The Persian hero holds two lions in his hands. The seal is attested in EE 65 and UCP $9 / 3$.

1033 See Section 5.7 .
} 
including a horse land, which implies that the family belonged to an upper social stratum in the hierarchy of the land-for-service sector. Their use of seals, their frequent presence as witnesses, and Udarna"s Iranian name point towards the same conclusion. Their horse land belonged to the hatru of the sēpirus of the troops, and Hanan-Yāma/Udarna? and Gadal-Yāma/Šabbatāya witnessed another transaction pertaining to the same hatru. This was perhaps the general administrative context of Rahìm-il's landholdings.

The only comparable group of texts related to Judeans are the documents on the community in Bìt-Gērāya. Although the groups differ in many ways, they show a similar relationship between the Murašus and the protagonists of the text groups. The protagonists had significant resources at their disposal, but their distressed financial situation or aspiration to expand their farming activities forced them to seek help from the Murašûs. This is a common pattern in the archive, and Judean landholders are usually attested only when they needed the services provided by the Nippurean family. Those Judeans who never sought such help or support are invisible to us. This aspect of the archive's composition needs to be taken seriously, as it can greatly affect the conclusions about Judean landholding in the Nippur region.

\subsubsection{Other Judean Landholders}

Apart from the documents discussed above, one more Judean landholder can be connected to a particular hatru. BE 1092 (13?-IX-4 Dar II) is a receipt of a sūtu rent of grain fields (zērū pi šulpi) in Appāru ša Tahmiya and Gammalē, which belonged to the hatru of the gardu. Šabbatāya/Hi-il-lu-mu-tu - a man of Judean origin ${ }^{1034}$ - held these lands together with Il-gabrī and Nabû-nā, the sons of Šuzzubu, and their anonymous colleagues. The same brothers appear again in IMT 32 (?-V-? Dar II) as holders of a bow land which was leased out for date cultivation. The communal nature of landholding is apparent again, as the brothers held this date plantation with two other named colleagues from the hatru of the gardu. The appellation gardu is somewhat elusive in Babylonia, but its semantic range corresponds to its Elamite counterpart kurtaš, which is a designation for state-dependent workers in the Persepolis archives. ${ }^{1035}$

The rest of the land properties (co-)held by Judeans cannot be linked to any particular hatru or estate. In two documents related to the same litigation over land properties in Gammalē and Išqallūnu (BE 10 118, 13-I-7 Dar II; and EE 111,

1034 The identification of this person as a Judean is based on his rare patronymic, which is attested only in IMT 94 (Hi-il-mu-tu) as the patronymic of a certain Šamā-Yāma.

1035 Stolper 1985, 56-59; Briant 2002, 429-439, 456-459; Tavernier 2007, 423-424; cf. CAD G, 50. 
date broken), seven Judeans and their anonymous brothers are attested as coholders of a bow land. The landholders belonged to two families, being sons of Tuūb-Yāma and Zabīnâ. Although the Judeans were holders of a bow land, they also owned land and houses that could be sold. They accuse Rīmūt-Ninurta of taking their lands illegally, whereas Rīmūt-Ninurta claims that he has bought them for 30 minas of silver from the sons of Țūb-Yāma (BE 10 118) and for 10 minas of silver from the sons of Zabinnâ (EE 111). These are very large amounts of silver, and they emphasise the fact that people in the land-for-service sector could own and sell valuable real estate.

In addition to the documents pertaining to the bow and horse lands, four texts relate to bit rittis and one text to a date garden (co-)held by Judeans. The earliest attestation of a Judean landholder and the second earliest text in the whole Murašû archive is BE 93 (26-II-13 Art I), in which Enlil-hātin/Murašû leases the bit ritti land of Arad-Gula and Hanan-Yāma to five people for sharecropping. As customary, any institutional affiliation of the bit ritti is not given, but as pointed out above, landholdings designed like this may also have belonged to a temple or the crown. Another bit ritti, held by Haggâ/PN and Mattan-Yāma/PN, is mentioned in passing in EE 24 (?-X-? Art I). The landholders rent two oxen from Enlil-šum-iddin to plough the fields in their bit ritti. The bìt ritti lands of Yadi-Yāma (BE 925 , 45) were discussed in Section 5.2.2.

There is only one document that refers to a Judean landholder not explicitly linked to the land-for-service sector or an institutional landholding. HananYāma/Aplâ had leased his date plantation (zēru zaqpu) in Bīt-Murānu by the Harri-Piqūdu canal to Rīmūt-Ninurta, who paid the imittu rent in 20 shekels of silver instead of dates (EE 34, 4-VII-7 Dar II). It is interesting that Hanan-Yāma bore the title sêpiru (see Section 5.4) and he had given an Iranian name Bagēšu ${ }^{1036}$ to his son. Gukka ${ }^{1037}$ the slave of Bagěšu, collected the rental payment from the sêpirus of Rìmūt-Ninurta. There is no reason to suppose that Hanan-Yāma was a high-ranking official like Mannukiya; more likely he was one of the petty officials attested in the Murašû archive. His duties perhaps brought him into regular contact with the Persians, which could have encouraged him to give an Iranian name to his son.

\subsubsection{Patterns of Judean Landholding}

The results of the previous survey of Judean landholders and landholdings conform to the general patterns of the Murašû archive. Judeans are primarily attested as holders of bow lands and bit rittis, and only one Judean landholder

1036 Tavernier 2007, 135 .

1037 Another Iranian name; Tavernier 2007, 187. 
cannot be linked to any institution or institutional landholding. Moreover, the Judean landholdings were regularly at the disposal of the Murašus as a result of a lease or as a security for a debt. This picture is somewhat skewed, of course, because we can only perceive Judeans from the viewpoint of the Murašu family who ran their business in a specific sector of the Babylonian economy. The majority of Judeans in the Nippur region were hardly ever in contact with the Murašûs, although it may well be that they were all integrated into the landfor-service sector.

There seems to be no reason to doubt that most Judean deportees worked in the land-for-service sector in Babylonia. The picture emerging from the Murašû archive is consistent with that from the environs of Yāhūdu: Judeans were settled in communities and assigned to certain administrative units which were still observable 150 years after the deportations from Judah. The strong Judean presence in Bìt-Gērāya and the hațru of the sēpirus emphasises this observation, but there are also other villages in which Judeans are regularly attested. Noteworthy examples are Gammalē ${ }^{1038}$ and Išqallūnu: ${ }^{1039}$ Judeans are present in every document pertaining to the former, and a group of Judeans owned houses in the latter (BE 10 118; EE 111). ${ }^{1040}$ The landholders in Išqallūnu bore exclusively West Semitic names, and, in addition to Judeans, Philistines obviously lived in this twin town of Ashkelon. ${ }^{1041}$ There is no evidence of a hatru of Judeans, but the administrative logic behind the local communities and the hatru of the seppirus was the same. It was practical to retain the basic communal structures which allowed the local officials to deal with the representatives of the community, not directly with each family unit.

The communal aspect of landholding characterises the transactions pertaining to Judean farmers. There is no direct evidence of landholdings being split into tiny fragments by inheritance divisions; rather, judging by their patronymics, the co-holders of land properties were often unrelated. As I argued above, the idea of shrinking landholdings is contradictory to the aims of the land-for-service sector. If land was readily available and the crown strived to increase agricultural output and tax flows, there was every reason to bring new lands under cultivation when the existing fields and gardens could not support their holders anymore.

It must also be emphasised that there was a lot of flexibility in the terminology pertaining to the land-for-service sector. A bow land was not a plot of

1038 Attested in BE 10 83, 92, 118; [EE 111]; PBS 2/1 115.

1039 Attested in BE 9 86a; BE 10 118; EE 111; IMT 17.

1040 On Gammalē and Išqallūnu, see Zadok 1978a, 311, 319; 1985, 137-138, 183.

1041 See Eph'al 1978, 80-83; Zadok 1978b, 61. 
standard size, designed to support one landholder and his family. Some bow lands could produce huge tax and rental payments, whereas others appear to be very tiny. In the same vein, the frequent references to anonymous coholders of bow lands attest that larger communities were involved in farming them. There were no fixed representatives of a particular landholding, as the same bow land could be represented by different people on different occasions.

Finally, it must be emphasised that farming communities and groups of colandholders were hardly homogenous. Some co-landholders of Judeans bore Babylonian names, and Philistine deportees must have composed the bulk of the original population in the village of Išqallūnu. These two phenomena - the survival of communities and their constant interaction with other deportees have important implications for the discussion of Judean culture and identity in the Nippur countryside. I will return to these questions in Section 5.7 below.

\subsection{Judean Officials}

The efficient collection of taxes and organisation of work and military service necessitated the presence of administrative personnel in Nippur and the surrounding countryside. Judeans are not attested among the higher functionaries of the hierarchy, but some minor officials were recruited from their ranks.

As I argued above, the Judeans attached to the hatru of the sêpirus were not sêpirus themselves, and there is no reason to suppose that the level of literacy was high among the Judean farmers. Hanan-Yāma/Aplâ is the single Judean sēpiru attested in the archive (EE 34). ${ }^{1042}$ The Iranian name Bagēšu, given to his son, suggests that Hanan-Yāma was in regular contact with the Persian authorities, which naturally fits his profession. Nothing is known about HananYāma's professional duties, because EE 34 pertains to the lease of his date plantation (see Section 5.3.4). However, there is no reason to suppose that he was a high-ranking official like Mannukiya; more likely he was one of the petty officials attested in the Murašû archive.

The duties of four Judean officials were directly related to the administration of the land-for-service sector. Išrib-Yāma/Pili-Yāma, the only Judean šaknu in the Murašu archive, managed the hațru of the šušannus of the storehouse (nakkandu). ${ }^{1043}$ As šaknus were not systematically recruited from among the

1042 On this text, see Bloch 2018, 344-347.

1043 See Stolper 1985, 89-93 for a discussion of this estate and its personnel. 
landholders of the pertinent $h a t+r u,{ }^{1044}$ it remains unclear if Išrib-Yāma himself held land in this organisation. He held the title of šaknu in 5-V-3 Dar II (BE 10 65), but a year later, Pamunu, a servant ( $a r d u)$ of Artahšar, is attested in the same position (PBS 2/1 205, 16-?-4 Dar II). ${ }^{1045}$ Išrib-Yāma was still involved in the management of the hatru and was perhaps in a superior position in relation to Pamunu, as the šaknu Pamunu collected the payments according to the written tablet (libbû šațāri țuppi) $)^{1046}$ of Išrib-Yāma. This does not mean that the tablet was written by Išrib-Yāma, and it is not a proof of Išrib-Yāma's literacy in cuneiform. Artahšar, the master of Pamunu - and obviously of Išrib-Yāma as well - has been identified with Artoxares, who appears in Ctesias' Persi$c a{ }^{1047}$ According to Ctesias, Artoxares was among the people on the winning side during Darius II's fight for the throne of Persia. The Murašû archive shows that like Gūbaru, Artahšar took over some of Prince Manuštānu's landholdings and personnel in Babylonia. Išrib-Yāma impressed his seal on BE 10 65. It depicts a Persian hero holding two monsters, with the god Ahura Mazda hovering above the scene. ${ }^{1048}$

A Judean called Il-yadin/Yadi-Yāma ${ }^{1049}$ was a servant ( $\left.a r d u\right)$ of Artahšar as well. He and Nidinti-Šamaš/Kartakku, another servant of Artahšar, collected a rental payment (zittu) originating from the fields of their master in PBS 2/1 84 ([Sîn-b]ēlšunu, 19-V-4 Dar II). The lands were taken on lease by the Murašûs, and, two years later, Rīmūt-Ninurta and Il-yadin are attested as co-creditors in Sîn-bēlšunu (PBS 2/1 121, 10-VI-6 Dar II). Il-yadin does not bear any title in the latter document, and Rīmūt-Ninurta appears to have been the main creditor who kept the pledged bow land at his disposal until the debt was paid back. Although Il-yadin is not attested in other documents, his colleague NidintiŠamaš is better known. He was the manager ( $p a q d u$ ) of Artahšar's estate and a frequent witness in the early reign of Darius II. ${ }^{1050}$ His co-occurrence with Ilyadin and the contents of PBS $2 / 184$ and 121 suggest that the Judean was also

\footnotetext{
1044 Stolper 1985, 85-88.

1045 On Pamunu, see Stolper 1985, 92 n. 89.

1046 On this expression, see CAD L, 173.

1047 Stolper 1985, 91-92.

1048 Bregstein 1993 no. 37.

1049 His patronymic has been preserved as $I a-a-d[a-]$ in PBS $2 / 184$ and $I a-d i-h u-i a-a$-[...] in PBS 2/1 121, and the restoration Yadi-Yāma is very likely.

1050 Stolper $1985,92+$ n. 88 (his reference to PBS $2 / 184$ is to be corrected: Nidinti-Šamaš is titled $a r d u$ instead of paqdu); Bregstein 1993, 442, 607. Note that he witnessed two documents pertaining to the hatru of the sêpirus of the troops, PBS $2 / 127,29$. On the title paqdu, see Stolper 1985, 22, 66-67; CAD P, 135-136.
} 
an official in charge of Artahšar's landholdings. Il-yadin had a seal which depicts two Persian heroes fighting against monsters (PBS 2/1 84). ${ }^{1051}$

Parysatis, the Persian queen and wife of Darius II, held lands in the Nippur region, which were managed by her paqdu Ea-bullissu. ${ }^{1052}$ A Judean called Mattan-Yāma/Amuše collected rental payments from the Murašûs on behalf of Ea-bullissu in PBS 2/1 50 (12-IX-3 Dar II $)^{1053}$ and witnessed another rental payment pertaining to Parysatis' holdings in P BS 2/1 60 (3-IV-3 Dar II). He impressed his iron ring on both documents. ${ }^{1054}$ Mattan-Yāma is also attested in EE 113 (?-?-33+ Art I), which does not refer to Parysatis or Ea-bullissu but is a contract between four Judeans and Enlil-šum-iddin. The Judeans, one of them Mattan-Yāma, owed a debt which they agreed to pay back by providing Enlilšum-iddin with forty paid workers and ten šušānus for a month. The document attests that human labour was used to pay off debts, ${ }^{1055}$ but unfortunately the text does not specify the relationship between the debtors and the workforce. However, BE 928 (18-VII-31 Art I) sheds some light on the institutional affiliation of the debtors: Šillimu/Yāhû-laqim, one of the co-debtors in EE 113, appears as a witness to rental payments pertaining to the lands of the queen's estate (é mí śá é.gal).1056

The emerging picture conforms to Stolper's hypothesis that Parysatis took over the landholdings of the former queen after the accession of her husband Darius II. ${ }^{1057}$ In the late reign of Artaxerxes I, a group of Judeans were attached to the queen's estate. The four Judeans were in a position to hire forty paid workers and order ten šušānus to work for the Murašûs, but their relationship to the workers is not made explicit. Given the fact that the Judeans were indebted to the Murašûs, the transaction should be seen in the same context as EE 92, in which Yāhû-natan and Bānia lease a canal from the Murašûs and pay the rent by assuming the maintenance work of the canal. As headmen of the village of Bìt-Gērāya, Yāhû-natan and Bānia had the resources of the community at their disposal. Likewise, the four Judeans of EE 113 were representatives of the local community, and they were important enough to be mentioned as witnesses in other documents as well. In the reign of Darius II, Parysatis gained control over the queen's estate and the landholdings attached to it, including the holding of Mattan-Yāma and his Judean colleagues. In this new situation,

\footnotetext{
1051 Bregstein 1993 no. 93 .

1052 See Stolper 1985, 63-64; Cardascia 1991. On Parysatis, see also Stolper 2006b.

1053 See Cardascia 1991, 367-368 for a helpful reconstruction of this broken document.

1054 Bregstein 1993 no. 281. The seal impression depicts a lion.

1055 Stolper $1985,81$.

1056 On this estate, see Stolper $1985,62-63$.

1057 Stolper 1985, 64.
} 
Mattan-Yāma became a servant of the paqdu of Parysatis' estate, collecting rental payments and witnessing documents relating to such payments. He was perhaps not an official in a strict sense, but rather the headman of a local community, who controlled the estate's landholdings and the flow of taxes to the coffers of the estate.

Finally, a Judean man called Barìk-Yāma, a servant ( $a r d u)$ of the mašennu official Artabara, ${ }^{1058}$ collected some oil from the subordinates of RīmūtNinurta (BE 10 6o, 25-IX-2 Dar II). He acted together with Bēl-iddin/Bēlbullissu, the sēpiru of the mašennu. Barik-Yāma did not impress a seal on the tablet and he is not attested in any other document.

Some Judeans worked as minor officials in the land-for-service sector of the Nippur region, but the number is small in comparison to the numerous attestations of Egyptian officials. Moreover, unlike Egyptians, Judeans are only attested on the lowest rungs of the administrative hierarchy. ${ }^{1059}$ Only two Judeans, one sēpiru and one šaknu, bore a formal title, but the Judean servants of high officials obviously acted in an official position as well. The Murašu archive provides examples of people who are sometimes designated as servants of high officials and royalty but bear an official title in other documents. ${ }^{1060} \mathrm{An}$ interesting feature that characterises Judean officials is the frequent use of seals, implying that they participated in transactions so often that it made sense for them to acquire one. The imagery of these seals and the hints they give of their owners' cultural identity will be discussed below in Section 5.7

\section{$5.5 \quad$ Judean Witnesses}

In almost half (45\%) of all occurrences in the Murašu archive, Judeans are attested as witnesses. Some Judean witnesses, such as Pili-Yāma and Udarna ${ }^{2}$, had a business relationship with the Murašû family, but 55 per cent of Judean witnesses are never attested as principals in the documents. It is well known that the parties of a transaction sought to have their family members, friends, and business partners as witnesses to their documents, ${ }^{1061}$ and the Murašû family also had its circle of frequent witnesses. ${ }^{1062}$ The testimony of such witnesses

\footnotetext{
1058 On Artabara and mašennu officials in general, see Stolper 1985, 45-49; Jursa and Stolper $2007,260$.

1059 Hackl and Jursa 2015, 168-172.

106o See, for example, the case of Nidinti-Šamaš/Kartakku above, and the case of Girparna? in Stolper 1985, 67, 96. See also Hackl and Jursa 2015, 161.

1061 von Dassow 1999b, 5-7; Still 2019, 169-170.

1062 Cardascia 1951, 20; Cussini 2013, 43-49.
} 
was required if the transaction was ever contested, and men close to the principal of the transaction were indispensable in the case of litigation. ${ }^{1063}$

Judeans witnessed transactions concerning their family members and other Judean acquaintances, but this was only sometimes the case. Pili-Yāma, for instance, witnessed two documents pertaining to Yadi-Yāma (BE 9 45; EE 98), as well as three others which do not pertain to any Judean principal (BE 934 ; IMT $7-8$ ). The three latter documents were written on the same day before the same witnesses, and they all concern Enlil-šum-iddin's business dealings. Mattan-Yāma/Širkā is attested three times as a witness to Rīmūt-Ninurta's transactions, but only one of the documents features Judean principals (BE 10 83; EE 34; PBS 2/1 203). Likewise, Udarna"'s son Hanan-Yāma witnessed a litigation concerning his father (BE 969 ), but he appears as a witness in three documents without Judean principals (BE 10 7, 84; PBS 2/1 107). These two men themselves are never attested as principals of a transaction, but they both owned a seal ${ }^{1064}$ and were obviously men of some importance. It is possible, of course, that Pili-Yāma, Mattan-Yāma, or Hanan-Yāma belonged to the Murašû family's circle of witnesses, but it is more likely that they acted in an official capacity or were considered neutral parties, who were occasionally asked to witness a document when they were available in Nippur. ${ }^{1065}$

\subsection{Socio-Economic Status}

\subsubsection{The Framework of the Archive: the Land-for-Service Sector}

The text groups discussed above shed light on different aspects of life in the Nippur countryside. The documents pertaining to Yadi-Yāma, Pili-Yāma, and the villagers in Bìt-Gērāya show few affinities with the texts relating to the hatru of the sêpirus. The former group lacks the keywords typical of the landfor-service sector, such as hatru, bow land, and šaknu, and it attests to the efforts of villagers and their representatives to make the best of their economic situation in the Babylonian countryside. On the other hand, Judeans attached to hatrus and Judean officials were evidently living in the framework of the land-for-service sector and under the control of high officials and royal estates. It is not immediately clear if the seeming difference between the two groups is

1063 Still 2019, 169.

1064 Mattan-Yāma: Bregstein 1993 no. 574; Hanan-Yāma: nos. 108 and 268.

1065 On neutral parties as witnesses, see Still 2019, 169-170. 
real or if it only results from the composition of the archive; as pointed out above, the Bìt-Geerayya texts predate the bulk of the texts in the archive, especially the cluster of texts pertaining to bow lands in 40 Art I -7 Dar II.

However, the structures of the land-for-service sector were not created in the beginning of Darius II's reign. Bow lands and hatru-like structures existed in the environs of Yāhūdu long before the Murašû archive. Given the importance of the land-for-service sector in the Nippur countryside, it is unlikely that the villagers in Bìt-Gērāya - many of them descendants of Judean deportees were left outside of it. Although bit ritti is an ambiguous term in this regard, it implies that Yadi-Yāma's landholdings were not exclusively his private property. At the same time, the case of Bìt-Gērāya reminds us that the landholders in the land-for-service sector were not deprived of their agency and that they could strive to improve their economic situation. This picture is corroborated by other texts as well. BE 10118 and EE 111 show that owning private lands and holding bow lands were not mutually exclusive, and Ahīqam and Ahīqar did much more than cultivate their landholdings in Yāhūdu and Našar. The texts pertaining to Bìt-Gērāya should be seen in this context.

In general, it has to be kept in mind that the Murašû archive emphasises certain social and economic aspects of life in the Nippur countryside. Because credit granting and agricultural management dominate the contents of the preserved texts, Judeans are usually attested when they needed assistance with farming their lands or fulfilling the state obligations imposed on them. Those who did not require such services had little reason to deal with the Murašû family. Alternatively, the Murašûs met some Judean minor officials when managing lands belonging to the state and royalty. This structural skew may lead to inaccurate conclusions about the economic status of agricultural communities, because their financial difficulties are more likely to be reflected in the archive than their ability to pay taxes and fulfil service obligations. Consequently, other economic activities than farming are obviously underrepresented. A couple of texts shed light on other ways of making a living in the countryside: in one case, a Judean fisherman and his colleagues lease nets from a servant of the Murašûs (PBS 2/1 208), ${ }^{1066}$ and in another a Judean herd the sheep and goats of Prince Aršam (PBS 2/1 148). In any event, half of the population is absent from the archive: not a single Judean woman is attested.

1066 The sequence of lessors' names and patronymics on lines 1-3 is unclear and it can be read in different ways. Compare, for example, the edition at CTIJ to Horowitz and Gheva 2017. In light of the fact that the fishermen lease five nets, the most probable number of lessors is five. One of them is Judean, Zabad-Yāma/Hinnī-Bēl. 


\subsubsection{Taxation and Service Obligations}

Given the fact that the Judeans in the Murašû archive were primarily attached to the land-for-service sector of the Babylonian economy, taxation and service obligations had a decisive impact on their life and economic situation. However, only two texts shed light on the taxation of Judean landholders in particular. These documents pertain to the taxation of the bow land held by Aqbi-Yāma, together with his co-landholders in the hatru of the sēpirus of the troops. Even in this case the payment was indirect, as members of the Murašu family paid taxes on behalf of landholders. In the first year of Darius II, Enlilšum-iddin paid the qēmu and bāru taxes (PBS 2/1 27), and three years later, the landholders owed 6o kurru of dates to Rīmūt-Ninurta, who had paid their taxes in silver (PBS 2/1 89). An instructive case is also BE 1065 , in which the Judean šaknu Išrib-Yāma collects the taxes incumbent on a number of bow lands. The payment of 2 minas of silver comprises the whole $i l k u$, the king's man (șa $b$ šarri), flour (qèmu), bāru, and any other presents to the house of the king (mimma nadānātu ša bìt šarri).

The terminology employed in these documents is representative of the Murašû archive as a whole. ${ }^{1067}$ The usual phrase covering the annual tax obligation is ilku gamrūtu șāb šarri qēmu ša šarri bāru u mimma nadānātu ša bìt šarri, meaning 'the whole ilku tax, the king's man, the king's flour, the bāru tax, and any other presents to the house of the king. In the Murašû archive, this tax obligation is normally paid in silver. The word $i l k u$ originally denoted a service obligation towards the state, but in the late fifth century, it had become an umbrella term which could include all other tax payments as well. In fact, it is customarily used alone, having the same general meaning as the entire long phrase. ${ }^{1068} S \grave{a} b$ šarri, the king's troops, still designated actual service in the sixth century, but the documents from the Murašû archive refer to it as a type of tax payment. ${ }^{1069}$ The flour tax (qēmu) relates to agricultural produce provided for the king. As grinding flour was considered a menial task, delivering flour to one's overlord can be seen as a symbolic act. The nature of the bàru tax an Iranian loanword meaning 'to carry' - is not well understood. ${ }^{1070}$ The litany of taxes paid in silver is completed by the reference to any other deliverables to the king (mimma nadānātu ša büt šarri), affirming that everything was included

1067 On taxation in the Murašû archive, see Cardascia 1951, 98-106; van Driel 2002, 226-273; Jursa 2011a.

1068 Cardascia 1951, 98-99; van Driel 2002, 254-259.

1069 van Driel 1989, 210-212; Stolper 2001, 123-127.

1070 van Driel 2002, 268-270. 
in the tax payment. Thus, it appears as if a whole range of obligations was neatly covered with a single payment in silver.

It has to be noted, however, that there was a real link between landholdings and service obligations in the late fifth century as well. This is emphasised by the texts from the second year of Darius II, which show how the holders of bow and horse lands in the Nippur region had to equip bowmen and horsemen and send them to Uruk. ${ }^{1071}$ The service was performed by the landholders themselves. Gadal-Yāma, the co-holder of a horse land, travelled to Uruk with a horse, arms, and other necessary gear of a horseman. This text group is exceptional in the Murašu archive, but the affair was perhaps not exceptional in itself. Ad hoc recruitment of soldiers would have been extremely impractical, especially when it came to horsemen and charioteers. As one cannot ride a horse or chariot - let alone engage in battle - without training, it would have been a waste of resources to equip unskilled farmers with very expensive animals and gear and then send them to perish in their first encounter with the enemy. Horses were not used in Babylonian agriculture, and, unlike in early modern Europe, the average farmer or landholder probably had no experience of riding or handling a horse. It therefore seems likely that Gadal-Yāma and his colleagues had received training and that they belonged to a permanent reserve of the army. Work service in the land-for-service sector was also concrete: two documents pertaining to Judean communities (EE 92, 113) show how a large group of people could be assigned to dig a canal or work for the Murašû family in order to pay back a substantial debt.

The documents from the environs of Yāhūdu corroborate the view that tax payments and concrete service obligations could exist at the same time. ${ }^{1072}$ Sūtu and imittu payments in produce and $i l k u$ payments in silver were delivered by proxies to the officials who managed the land-for-service sector, and these payments should be considered taxes. At the same time, landholders hired substitutes to perform work and military service on their behalf. Although actual work or military service is only sporadically attested in the environs of Yāhūdu and in the Murašû archive, the preserved texts show that such levies were imposed and that $i l k u$ payments in silver did not cover all service obligations. There are obvious reasons why concrete military and work service is rarely attested in the Murašû archive: the service obligations were not incumbent on the Murašûs, and they only touched upon the Nippurean family if landholders needed credit to fulfil their duties. If a šaknu ordered thirty landholders in his hatru to travel to Elam, this left no traces in the archive.

1071 Section 5.3.2.4.

1072 See Chapter 4. 
It also has to be taken into account that the average bow land in the late fifth century does not appear to have been cultivated by a single farmer and his family but a larger group of co-landholders. ${ }^{1073}$ The size of bow lands varied significantly, and the tax and service obligations had to vary respectively. In any case, a larger group of landholders was obviously better suited for fulfilling the service obligations, and the single farmer did not need to balance between the agricultural duties and his other obligations. The communal aspect of landholding and the attachment of bow lands to hatrus and larger estates imply that substitutes could easily be recruited locally.

Indebtedness among landholders and their strained economic situation in relation to the Murašû family are characteristic features of the Murašu archive. ${ }^{1074}$ They are reflected in the texts pertaining to Judeans as well: YadiYāma and his colleagues had to lease Yadi-Yāma's pledged landholdings from the Murašûs, and Rahìm-il's landholdings had come into the disposal of the Nippurean family. The documents pertaining to Ahīqar's activities show that the same difficulties also touched upon some landholders in the environs of Našar. However, it is impossible to know if this picture applies to landholders in the land-for-service sector in general. We are again dependent on the available sources, which illustrate the situation from the perspective of the credit grantor. If a landholder did not need credit, this left no traces in the archives of the businessmen in the land-for-service sector.

We may conclude that Judean landholders in the land-for-service sector were subject to tax payments in silver and to concrete work and military service. Although tax payments in silver are prevalent in the Murašu archive, the central aim of the whole tax regime was to provide the state with workers and soldiers, not to fill the Persian treasuries with tons of the precious metal. ${ }^{1075}$ However, taxes paid in silver could be used to hire troops and labour locally. It is therefore likely that many Judeans had to serve the state as workers or soldiers not only in Babylonia but also in other parts of the empire. The burden of these obligations on a single farmer remains unclear; ${ }^{1076}$ although there are symptoms of indebtedness among Judean landholders, there are reasons to suppose that such cases are overrepresented in the Murašû archive.

\subsubsection{Dependency and Freedom}

The majority of Judeans in the Murašû archive are farmers, and a small number worked as minor officials in the land-for-service sector. There are no

1073 Sections 5.2 and $5 \cdot 3$.

1074 Stolper 1985, 104-114.

1075 Jursa 2011 .

1076 See van Driel 2002, 270-272. 
Judean chattel slaves in the archive, and the Judeans called slaves (ardu) of high officials and royalty were obviously officials themselves. Rather than being somebody's slaves, the Judeans' freedom was limited by the constraints of the land-for-service sector. Landholdings and the incumbent obligations were an effective means of control: as bow lands were hardly ever sold, according to the available evidence, it is likely that they were principally inalienable. ${ }^{1077}$ Accordingly, landholders had to organise the farming of their plots one way or the other in order to pay the pertinent taxes and fulfil service obligations. Although landholders could lease out their lands and hire substitutes to perform work or military service, they were eventually tied to the land and to the obligations attached to it. As the substitutes were hired locally, the burden of work and military service rested on the rural population. ${ }^{1078}$ Moreover, at least the holders of horse and chariot lands had to be able to provide the state with trained soldiers, which implies that some members of the rural population could be designated as farmer-soldiers in reserve.

Unlike in the environs of Yāhūdu, Judeans are not explicitly called šušānus in the Murašû archive, although the term is well attested, especially in the names of hatrus. ${ }^{1079}$ As discussed in Section 4.2.2, the term refers to dependent people who were attached to the state or landed estates and who could not be sold into chattel slavery. Despite the lack of direct evidence, it is probable that the status of šušānu applied to some part of the Judean population in the environs of Nippur. An important text in this regard is EE 113, in which four Judeans provide Enlil-šum-iddin with forty paid workers and ten šušānus to pay a back a debt. This text seems to imply that there were two sorts of people in rural communities: those who had to be actually hired and those who could be sent to work without salary. In light of the evidence from Yāhūdu, it seems likely that the holders of bow lands predominantly belonged to the category of šušānus. Stolper might be right in suggesting that ' $\mathrm{t}] \mathrm{he}$ frequency of the term šušānu in characterizing hațrus and their members indicates that this status was typical and perhaps universal among Babylonian feudatories.' ${ }^{\prime 080}$

The context of the land-for-service sector proved to be a successful way to control Judean deportees and their descendants for more than 150 years after the deportations to Babylonia. Although some Judeans held large plots of land and they could work as minor officials and engage in business activities, the constraints of landholding effectively limited their freedom. There was no need to enslave the deportees. As it was not possible to sell the plots and get rid

1077 Stolper 1985, 25.

1078 See Jursa 2011a.

1079 On šušānus in the Murašû archive, see Stolper 1985, 72-82; van Driel 2002, 210-211.

108 o Stolper $1985,82$. 
of the incumbent obligations, ties to the land effectively attached Judean landholders to the Babylonian countryside.

\section{$5 \cdot 7 \quad$ Culture}

Like other legal documents from Babylonia, the Murašû archive is a difficult source for the study of culture and identity among the rural population. The texts pertain to the economic activities of a Babylonian family, and Judeans appear in the documents only sporadically. The Murašû archive has one advantage, however: seal impressions on the tablets are abundant, and nineteen seals used by Judeans are also attested. Because there are clearly distinguishable patterns of seal use in the archive, the choice of seals appears to adhere to the preferences of their users. The imagery of the seals can therefore reveal something about the Judean seal users as well.

\subsubsection{Seal Use}

The seals used by Judeans are an important source of information about the taste and preferences of their users. However, some caution needs to be exercised: the use of a certain seal does not necessarily imply that its imagery reflected its user's values or beliefs. In any case, Bregstein's analysis of sealing practices in the Murašu archive highlights some differences in the seal choice between various social and ethnic groups. ${ }^{1081}$ As the number of different seals in the Murašu archive is close to $700,{ }^{1082}$ these statistical differences cannot be taken as completely incidental. Bregstein's criteria for identifying Judeans are somewhat different from the ones used in the present study, ${ }^{1083}$ and the figures which she provides cannot be used as such. Table 2 lists the seal users whom I identify as Judeans.

Following Bregstein's typology, the seals used by Judeans can be assigned to four different categories. ${ }^{1084}$ The two largest ones are contest scenes ( 6 attestations, $38 \%)^{1085}$ and Western-style rings (5 attestations, $\left.31 \%\right) .{ }^{1086}$ Three seal

\footnotetext{
1081 Bregstein 1993, 366-373.

1082 Bregstein catalogues 657 seal impressions in her dissertation. Some twenty or so seal impressions from Istanbul need to be added to this number. Bregstein $1993,5^{1-} 5^{2}+\mathrm{n} .8$.

1083 Bregstein $(1993,226)$ does not include people who bore non-Judean personal names but whose fathers had Judean names. At the same time, she apparently considers some nonYahwistic personal names as distinctly Judean, although she only names the Yahwistic element as a criterion for identification (Bregstein 1993, 226 but cf. 577).

1084 Bregstein 1993, 71-108.

1085 Nos. 16, 31, 37, 91, 93, 108.

1086 Nos. $559,568,571,574,578$.
} 
impressions depict animals (19\%), ${ }^{1087}$ and the impression with a goatfish and crook (no. 491) is to be assigned to the category of composite and humanheaded monsters (6\%). One unclear ring impression (no. 642) cannot be assigned to any of these categories (6\%).

The first remarkable feature of Judean seal usage is the large number of Western-style rings and rings in general. By 'Western-style rings', Bregstein refers to motifs which were not traditionally Babylonian but originated in the Greek-speaking Eastern Mediterranean region. The use of metal rings in general was a novelty in Babylonia, where stone was traditionally used to produce stamp and cylinder seals. ${ }^{1088}$ Only $10 \%$ of the seals in the Murašû archive were

TABLE 2 Judean seal users in the Murašû archive

\begin{tabular}{|c|c|c|}
\hline Person & Document & Description of the seal \\
\hline $\begin{array}{l}\text { Yadi-Yāma/Banā-Yāma } \\
\text { and brothers }\end{array}$ & BE 925 & $\begin{array}{l}\text { Ring: nude couple embracing } \\
\text { (Bregstein no. } 578 \text { ) }\end{array}$ \\
\hline Yadi-Yāma/Banā-Yāma & BE 945 & $\begin{array}{l}\text { Ring: different from the one in } \\
\text { BE } 925 \text {; design is unclear (no. } \\
642 \text { ) }\end{array}$ \\
\hline Udarna'/Rahīm-il & BE 969 & $\begin{array}{l}\text { Cylinder: lion attacks a bull or } \\
\text { boar (no. } 362)\end{array}$ \\
\hline Hanan-Yāma/Udarna? & BE 969 & $\begin{array}{l}\text { Cylinder: Babylonian hero } \\
\text { holds a bull, crescent moon is } \\
\text { above the bull's head (no. 108) }\end{array}$ \\
\hline Hanan-Yāma/Udarna? & PBS 2/1 107 & Stamp: bull (no. 268) \\
\hline Gadal-Yāma/Rahīm-il & EE 65 & $\begin{array}{l}\text { Cylinder: Persian hero stands } \\
\text { on two sphinxes and holds two } \\
\text { lions (no. 16) }\end{array}$ \\
\hline Gadal-Yāma/Rahīm-il & UCP $9 / 3$ & $\begin{array}{l}\text { Cylinder: Persian hero stands } \\
\text { on two sphinxes and holds two } \\
\text { lions (no. 16) }\end{array}$ \\
\hline Išrib-Yāma/Pili-Yāma & BE 1065 & $\begin{array}{l}\text { Cylinder: Persian hero holds } \\
\text { two monsters, Ahura Mazda } \\
\text { hovers above him (no. 37) }\end{array}$ \\
\hline
\end{tabular}

1087 Nos. $268,281,362$.

1088 Bregstein 1993, 52-54, 94-97. 


\begin{tabular}{|c|c|c|}
\hline Person & Document & Description of the seal \\
\hline Mattan-Yāma/Širkā & BE 1083 & $\begin{array}{l}\text { Ring(?): seated woman wearing } \\
\text { a robe and crown holds a } \\
\text { branch or stalk (no. } 574)^{\mathrm{a}}\end{array}$ \\
\hline Mattan-Yāma/Širkā & EE 34 & Broken (see no. 574$)$ \\
\hline $\begin{array}{l}\text { Banā-Yāma/x-na-din- } \\
\text { numun(?) }\end{array}$ & BE 10118 & $\begin{array}{l}\text { Ring(?): soldier holding a spear } \\
\text { and shield (no. } 559)^{\mathrm{b}}\end{array}$ \\
\hline Zabad-Yāma & EE 89 & $\begin{array}{l}\text { Ring: bald fat man sitting with } \\
\text { snake/s (no. } 571)\end{array}$ \\
\hline Hanan/Padā-Yāma & EE 107 & $\begin{array}{l}\text { Stamp(?): goatfish and crook } \\
\text { (no. 491) }\end{array}$ \\
\hline Rahīm/Banā-Yāma & $\mathrm{PBS} 2 / 15$ & $\begin{array}{l}\text { Stamp: Persian hero holds a } \\
\text { monster and a spear (no. 91) }\end{array}$ \\
\hline Mattan-Yāma/Amušê & PBS $2 / 150$ & Ring: lion (no. 281) \\
\hline Mattan-Yāma/Amušê & PBS $2 / 160$ & Ring: lion (no. 281) \\
\hline Il-yadin/Yadi-Yāma & PBS 2/1 84 & $\begin{array}{l}\text { Cylinder: two Persian heroes } \\
\text { with daggers hold monsters } \\
\text { (no. 93) }\end{array}$ \\
\hline Yāhû-natan/ & PBS 2/1 119 & Stamp: Persian hero holds two \\
\hline Mattan-Yāma & & lion-monsters (no. 31) \\
\hline Abī-Yāma/Šabbatāya & PBS $2 / 1218$ & $\begin{array}{l}\text { Ring: crouching naked man } \\
\text { (no. } 568)\end{array}$ \\
\hline
\end{tabular}

a According to Bregstein 1993, 979, the impression resembles a ring, although the caption reads na ${ }_{4} \cdot$ kišib.

b See the previous footnote; Bregstein 1993, 964.

Western-style rings, but the number is twofold among the people with a West Semitic name or patronymic (19\%) and threefold among Judeans (31\%). Rings, regardless of imagery, count for $33 \%$ of the seals in the whole corpus, $50 \%$ of the seals used by people with a West Semitic name or patronymic, and $44 \%$ of the seals used by Judeans. ${ }^{1089}$

1089 The figures in the Murašû archive in general and the people with West Semitic names are adopted from Bregstein 1993, 225. I have calculated the percentage of people with a West Semitic name or patronymic by combining the data from the fourth and sixth columns of Bregstein's table. 
Another peculiar aspect is the prominence of contest scenes on the stamp and cylinder seals used by Judeans. The scenes depict heroes who fight against monsters and animals or who hold subjugated creatures in their hands. The heroes can be divided into two categories according to their clothing, which Bregstein defines either as Babylonian or Persian. ${ }^{1090}$ The contest scenes with a Persian hero constitute $13 \%$ of the seals in the whole corpus, $15 \%$ of the seals used by people with West Semitic names or patronymics, and $31 \%$ of the seals used by Judeans. The scenes with a Babylonian hero count for $10 \%$ of the seals in the whole corpus, $10 \%$ of the seals used by people with West Semitic names or patronymics, and 6\% of the seals used by Judeans. ${ }^{1091}$

A scene that is never attested on the seals used by Judeans, and very rarely on the seals of people with West Semitic names or patronymics (3\%), is that of worship. ${ }^{1092}$ Depicting a man - namely, 'a worshipper' - standing alone or before divine symbols or creatures, it was one of the standard motifs of Babylonian seal impressions in the sixth century. ${ }^{1093}$ The scene is attested in $8 \%$ of the seal impressions in the Murašu archive. Favoured by scribes and regular witnesses of the documents, it was also used by people with Iranian names. ${ }^{1094}$

Based on the rarity of worship scenes on the seals used by Judeans and other people with West Semitic names, Bregstein argues that these people deliberately avoided scenes depicting foreign religious rituals. ${ }^{1095}$ However, when the texts from the environs of Yāhūdu have now become available, her statement needs to be adjusted. Ahīqam's seal on By depicts the Babylonian worship scene, even though Ahīqam's patronymic Rapā-Yāma and the Yahwistic names of his sons leave little doubt about his Judean origin. ${ }^{1096}$ Using a seal with the worship scene was evidently not unthinkable for someone dealing regularly with royal officials. Moreover, it has to be emphasised that the seals used by Judeans in the Murašu archive did contain other religious symbolism. The seal of Hanan-Yāma/Udarna? depicts the crescent moon above the bull held by the Babylonian hero (no. 108), and the god Ahura Mazda hovers above the Persian hero on the seal of Išrib-Yāma (no. 37). It is very unlikely that the crescent

\footnotetext{
1090 Bregstein 1993, 73-79.

1091 Bregstein 1993, 225.

1092 Bregstein 1993, 225.

1093 Bregstein 1993, 82-85; Ehrenberg 1999, 15-25, 43-44.

1094 Bregstein 1993, 189-205, 225, 233-234.

1095 Bregstein 1993, 227, 234-235.

1096 See Section 4.3.6.3.
} 
refers to something or someone else than the moon god, and it would be dangerous to suggest that the Judeans simply equalled Persian Ahura Mazda with Yahweh.

Judeans did not avoid religious imagery on their seals, and the reasons for differing preferences need to be sought in local traditions and social structures. One decisive factor seems to again be the division between the urban upper class and the rest of society. Judeans, like other people with West Semitic names, favoured rings and imagery from the Eastern Mediterranean, both of which were novelties in Babylonia. The worship scene, on the other hand, had a long history in Babylonia and it was traditionally used by scribes. ${ }^{1097}$ Thus, it is not surprising to find that the scene was very popular among the scribes and frequent witnesses of the Murašu documents: of all people attested in the archive, these men most likely belonged to the Nippurean urban upper class. At the same time, the scribes and regular witnesses used Western-style rings $(5 \%)$ and rings in general (19\%) much less frequently than all seal users in the archive $\left(10 \%\right.$ and $33 \%$, respectively). ${ }^{1098}$ This comparison suggests that traditional imagery was favoured by the urban Nippureans, whereas Judeans and other people with West Semitic names were open to international influences and did not share the same traditional values as the urban upper class. ${ }^{1099}$

A surprising feature of Judean seal usage is the exceptional frequency of Persian contest scenes. Thirteen per cent of all seal impressions in the archive belong to this category, and the figure is roughly the same among people with Babylonian, Iranian, and West Semitic names. ${ }^{1100}$ However, almost one third of the seals used by Judeans depict this scene. ${ }^{1101}$ The scene with the Persian hero was not traditionally Babylonian but created during the reign of Darius I. ${ }^{1102}$ The novelty of this imagery may again explain the Judean preference for it.

Judean seal use does not exhibit aniconic or marked religious tendencies. Different religious symbols and motifs were employed, but Judeans often used

\footnotetext{
1097 Bregstein 1993, 191-192.

1098 Bregstein 1993, 191, 200. Seventeen per cent of scribal seals were rings with Western-style compositions, but Bregstein notes (191) that they also employ Mesopotamian symbols.

1099 Bregstein (1993, 191-197, 200-202) acknowledges the cultural factors which influenced the seal choice of scribes and regular witnesses, but she fails to notice the sociocultural reasons behind the seal choice of Judeans and other people with West Semitic names (218-238).

1100 Bregstein 1993, 220-221, 225.

1101 Because Bregstein's criteria for identifying Judeans are different, the preference for Persian contest scenes does not appear so strikingly in her figures (1993, 226-227). She proposes that an avoidance of other types of images might explain this preference.

1102 Bregstein 1993, 76-79.
} 
seal types and imagery that were new in Babylonia. They were open to Eastern and Western novelties, whereas the Babylonian urban upper class preserved older traditions in their choice of seals.

\section{5·7.2 Naming Practices}

Because we can only identify Judean families on the basis of Yahwistic names, it is not possible to say what percentage of Judeans used such names in the late fifth century. It becomes clear, however, that in addition to Yahwistic names, Judeans in the Murašû archive bore West Semitic, Akkadian, and Iranian names, including names which refer to other deities than Yahweh. The use of Akkadian and non-Yahwistic West Semitic names is by no means surprising, but the adoption of Iranian names is interesting, as it shows that the Persian rule affected naming practices even in the Babylonian countryside. Table 3 summarises the data on Judean naming practices in the Murašû archive. The reader immediately notices differences in naming practices between Judean fathers and sons. This phenomenon, first observed by E.J. Bickerman, ${ }^{1103}$ will be discussed in a larger context in Section 8.5.

Two Judeans, Udarna ${ }^{2} /$ Rahīm-il and Bagēšu/Hanan-Yāma, bore Iranian names. The use of Iranian names in these families seems to result from their interaction with Persian officials. The family of Rahīm-il held several plots, including a horse land, in the Nippur region, and their large-scale landholding makes it probable that the family had closer interaction with the Persian administration than the average Judean landholder (Section 5.3.3). Bagēšu's father Hanan-Yāma (EE 34) was a sēpiru, which suggests that he was also regularly in touch with the Persians. If Iranian names were not simply trendy, they

TABLE 3 Judean naming practices in the Murašû archive

\begin{tabular}{lcrlr}
\hline & Patronymics & \multicolumn{3}{c}{ First names } \\
\hline $\begin{array}{l}\text { Names borne } \\
\text { by Judeans }\end{array}$ & 41 & & 60 & \\
Yahwistic & 19 & $46 \%$ & 40 & $67 \%$ \\
West Semitic & 10 & $24 \%$ & 15 & $25 \%$ \\
non-Yahwistic & & $22 \%$ & 3 & $5 \%$ \\
Akkadian & 9 & $2 \%$ & 2 & $3 \%$ \\
Iranian & 1 & & & \\
\hline
\end{tabular}

1103 Bickerman 1978. 
were perhaps seen as a way to get closer to the administrative elite in the landfor-service sector.

There are two noteworthy examples of fluctuation in the spelling of Yahwistic names. The West Semitic name Mattan-Yāma ('Gift of Yahweh') is often spelled in the quasi-Akkadian form Mannu-danni-Yāma ('Who is stronger than Yahweh?'). ${ }^{104}$ There are two persons whose name is attested in both variants, ${ }^{1105}$ and, in one case, the same scribe employed both orthographies. ${ }^{1106}$ Two different factors may contribute to this phenomenon: on the one hand, cuneiform scribes often had difficulties in spelling non-Akkadian names, and they were perhaps tempted to use a quasi-Akkadian orthography to render the West Semitic name. On the other hand, it is possible that the Judeans themselves played with the ambiguity of their name, using a quasi-Akkadian form in the public sphere. ${ }^{1107}$

There is also ambiguity in the way in which the patronymic of Yadi-Yāma's father is spelled. Three times the patronymic is spelled $B a-n a^{-2}$-dingir.meš (BE 925 , 45; EE 98), reflecting the name Banā-il. However, the patronymic is once spelled Ba-na-ia-a-ma (EE 2), reflecting the Yahwistic name Banā-Yāma. Because two different scribes employed the form Banā-il but there are no parallel cases of representing the Yahwistic element with dingir.meš, it is likely that Yadi-Yāma himself used the forms Banā-il and Banā-Yāma interchangeably when referring to his father. ${ }^{1108}$

Finally, full names and hypocoristics formed from Yahwistic names were sometimes used interchangeably. Hanan-Yāma/Udarna? is attested with his full name in three documents (BE 969 ; BE 10 7; PBS 2/1 107), but the hypocoristic Hananī (Ha-an-na-ni- $\left.{ }^{-}\right)$is used in BE 10 84. The name Gadal-Yāma appears twice in its hypocoristic form $[G] a-d a-a l^{2}-a$ (BE 9 86a) or Ga-da-al-ia (EE 65).

\subsubsection{Conclusion}

The texts from the Murašû archive refer to numerous ethnic minorities living in the Nippur countryside. Although deportees were originally settled in communities according to their origin, the population of the settlements had become diverse by the late fifth century. A noteworthy example of this phenomenon is Išqallūnu, a village named after the Philistine city of Ashkelon: it was

\footnotetext{
1104 The names are attested in BE 10 83; EE 24, 34, 113; PBS 2/1 50, 53, 60, 119, 148, 203. See the discussion in Stolper 1976, 26-27; Pearce and Wunsch 2014, 64, 66; Pearce 2015, 23-24.

1105 One cluster of texts is EE 113; PBS 2/1 50, 60; another one is BE 10 83; EE 34; PBS 2/1 203.

1106 BE 10 83; EE 34.

1107 These ideas are expressed in some form already in Coogan 1974, 11; Stolper 1976, 26-27; Pearce 2015, 23-24.

1108 Cf. Zadok 1979a, 12.
} 
one of the places with significant Judean inhabitation. ${ }^{1109}$ In addition to other deportees, Judeans were also in interaction with the indigenous Babylonian population and the Persian administrators of the land-for-service sector. The culturally diverse environment in which Judeans lived is reflected in several ways in the texts.

Judean seal users chose their seals on sociocultural grounds: they used seals with diverse religious imagery but favoured Western and Persian seal types, which were not traditional in Babylonia. They rarely used Babylonian seal types, which suggests that the cultural preferences of the Babylonian urban elite were quite different from those of the multi-ethnic rural population. Nevertheless, at least some Judean landholders were in regular contact with cuneiform scribes who belonged to this Babylonian urban elite. The ambiguity of some Judean names may attest to their efforts to support their own naming traditions but, at the same time, use names that sounded familiar to a Babylonian ear.

In addition to West Semitic anthroponyms, Judeans used Babylonian and Persian names. The adoption of Persian - and perhaps also Babylonian names - was related to an effort to get closer to the governing elite of the landfor-service sector. At the same time, the persistence of Yahwistic names in late fifth-century Babylonia implies that some descendants of Judean deportees still supported their own naming traditions.

\subsection{Conclusion}

As the Murašu archive focuses on business activities related to the land-forservice sector of Babylonian agriculture, only certain population groups in the Nippur region are represented in it. The clients of the Murašû family were predominantly holders of state lands encumbered with tax and service obligations. Another important group in the archive are state officials and servants of estate owners, from whom the Murašus leased canals and lands and to whom they paid taxes and rental payments. Judeans are attested among both groups, as landholders and as minor officials.

The Judean landholdings varied in size and juridical status. Although Judeans owned some private land as well, the evidence from the Murašu archive primarily pertains to institutional landholdings such as bow lands, horse lands, and bit rittis. None of these designations referred to a plot of standard size, as the extent of bow lands and the number of pertinent landholders varied

1109 See Section 5·3.5. 
greatly. Landholding was often collective, and several people shared responsibility for a single plot of land. Landholders and their landholdings were grouped together in administrative units called hatrus, which were managed by a number of officials and royal estates. Many Judeans belonged to the hatru of the sēpirus, which was eventually supervised by the governor of the province of Babylon. The landholders themselves were not Aramaic scribes, or sēpirus; thus, the names of these hatrus refer to high officials in charge of tax revenues in the Nippur region. Accordingly, there is no evidence of widespread literacy among Judeans, and only a single Judean sēpiru is attested in the Murašû archive.

Although the holders of state lands could not apparently alienate their holdings, they could lease them out, possess private land, and strive to improve their income in other ways. A good example of this is found in the villagers of Bìt-Gērāya, whose efforts in expanding agricultural production are reflected in the documents pertaining to Pili-Yāma, Yadi-Yāma, and Yāhû-natan. These people were not mere serfs under the control of feudal lords, and it is thus dangerous to apply the terminology of European feudalism to the Babylonian land-for-service sector. ${ }^{1110}$ Annual tax payments and the fulfilment of more or less regular service obligations appear to have been the primary constraints of their freedom. The majority of Judean landholders in the land-for-service sector co-held modest bow lands with several colleagues, but some Judeans had significantly larger holdings. Rahìm-il held several bow lands and a horse land, and judging by the Iranian name of his son and the frequent seal usage among the family, their socio-economic status was rather high.

Some Judeans were involved in the management of the land-for-service sector as minor officials in the service of royalty and high officials. However, they apparently did not succeed to the middle and higher rungs of the administrative hierarchy. Judean officials are often called slaves (ardus) of high officials, but the word obviously refers to hierarchical subordination. Judean chattel slaves are not attested in the archive. Some significant sectors of the Babylonian rural economy are seriously underrepresented in the archive: two documents indicate that Judeans also worked as fishermen and herdsmen.

Analysis of Judean seal use reveals that Judeans did not avoid Persian and Babylonian religious imagery, but their preferences were very different from those of the Nippurean upper class. Judeans favoured ring seals, which were a novelty in Babylonia, and the motifs of their seals primarily originated from

1110 On this question, see Cardascia 1983; Stolper 1985, 24-25 + n. 96 . 
Persia and the Eastern Mediterranean. This implies that Judeans were culturally quite distinct from the old families of Nippur. At the same time, the multiethnic landscape of rural Babylonia is reflected in Judean naming practices: in addition to Yahwistic and other West Semitic names, Judeans used Babylonian and occasionally Iranian names.

The Murašu archive constitutes the last significant corpus of cuneiform evidence on Judeans in Babylonia. Only a single text survives from the fourth century, drafted in the eighth regnal year of Artaxerxes II or III. ${ }^{1111}$ Rabbinic writings from the early first millennium CE shed light on the life of Judean - or better put, Jewish - communities again.

1111 TuM 2-3 123. Because four people sealed the tablet, it was hardly written in the eighth year of Artaxerxes I (Zadok 2002, 45). 